\title{
Looking for High Quality Accreditation in Higher Education in Colombia
}

\author{
Jesús Alfonso Pérez Gama ${ }^{1}$, Anselmo Vega Vega ${ }^{2, *}$ \\ ${ }^{1}$ San José Higher Education Foundation, Colombia \\ ${ }^{2}$ District University Francisco José de Caldas, Bogotá, Colombia
}

Copyright $\bigcirc 2017$ by authors, all rights reserved. Authors agree that this article remains permanently open access under the terms of the Creative Commons Attribution License 4.0 International License

\begin{abstract}
We look for the High Quality Accreditation of tertiary education in two ways: one, involving large amount of information, including issues such as self-assessment, high quality, statistics, indicators, surveys, and field work (process engineering), during several periods of time; and the second, in relation to the information contained there about High Quality, which involves the development of an intelligent architecture based on both knowledge and models towards competitiveness. Mathematical and computational models for dynamic and structural analysis of the academic governability integrate the engine for this architecture. We specially consider that the processes of High Quality Accreditation demand a great effort, with the participation of numerous people and faculty members, and the compliance with government regulations. Architecture makes it easy to walkthrough top down and bottom up: from macro to micro level of data (and vice versa), covering the whole processes of the university, in order to verify the full compliance with the accreditation rules, policy and quality assurance of the entire academic programs. These architectures allow us to follow up the progressive enhancement in search of the academic excellence.
\end{abstract}

Keywords High Quality Architecture, Intelligent Architecture, Self-assessment, Higher Education, Accreditations of High Quality, Governability, Competitiveness, Productivity

\section{Post War Conflict Situation \& Higher Education Crisis in Colombia}

After more than one half century of internal war, nowadays we celebrate the peace agreement supported by the International Community. We prepare for a post-conflict situation, which will extend over the next 20 years in which thousands of demobilized and displaced persons need to be prepared, requiring a short-term re-qualification of the workforce. Given the shortfall of 100,000 ICT (Information and Communication Technologies) engineers and the triple of technologists and programmers, our proposal aims to be a disruptive innovation to face with high technology the post-agreement and the alarming digital divide of human talent in this country. [4] [17] [24] [27] [31]

The problems of the young people who enter the University have multiple edges:

- The disintegration of the educational model in post-modernity pari passu, the low competitiveness of the EDUCATIVE Sector because of its very questionable quality in relation to local and international results

- Our terrible dilemma in the field of Competitiveness is that our infrastructure and university facilities are from the Industrial Society (i.e. 19th century), we are teachers of the Information Society (i.e. 20th century) but our students are from the Knowledge Society (XXI century)...

- The recurring underperformance of high school students in PISA and TIMMS that triggers dropout in the first semester of careers associated with ICT

- The deficiency in teaching productivity that affects the success in High Quality, as a critical factor

- The poor solutions that have been implemented with unsatisfactory results. The recent encouragement to postgraduate teachers is insufficient because it favors only a small part of the population. 


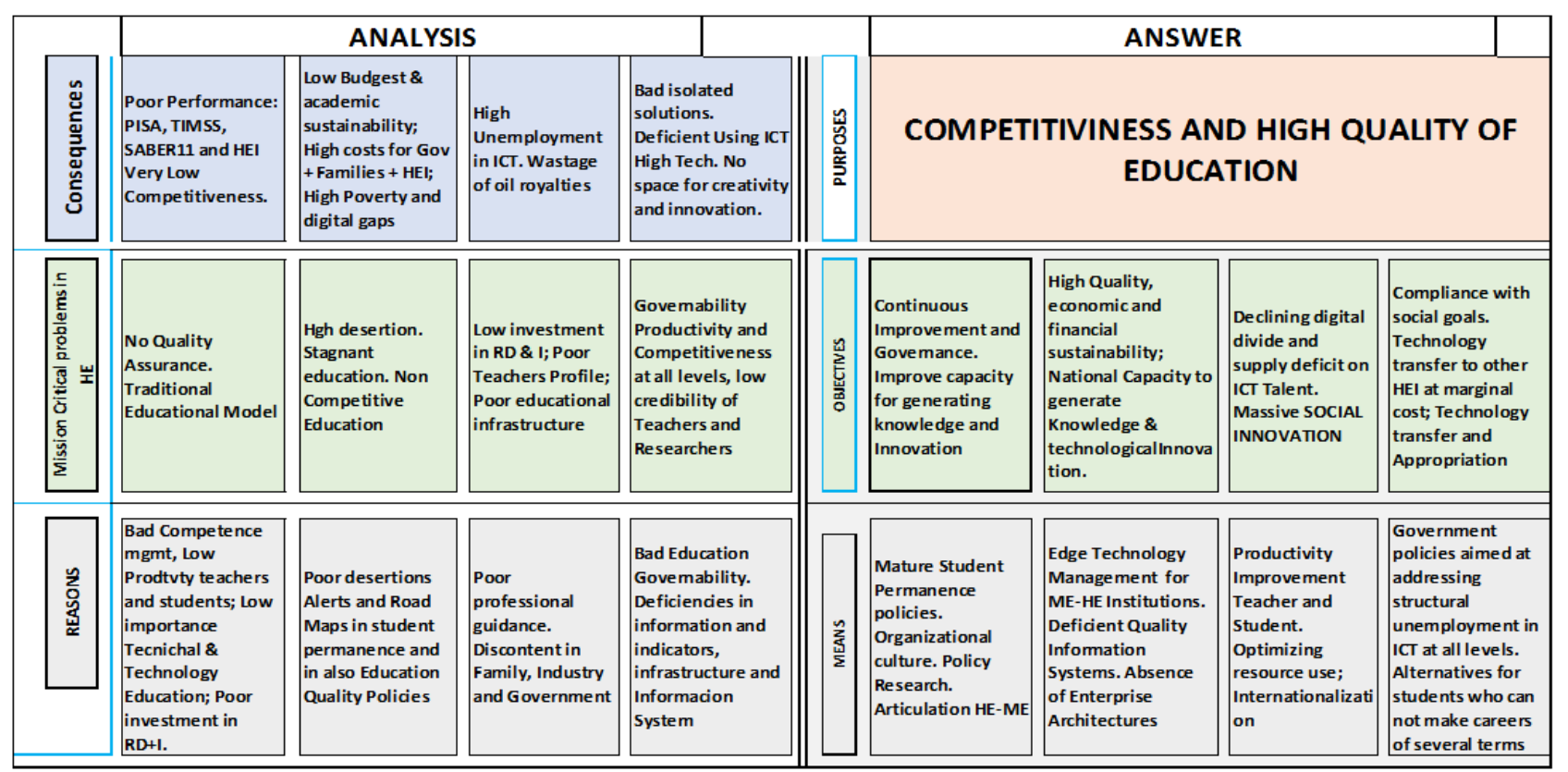

Figure 1. Education Sector Matrix

\subsection{Concomitant Effects}

The production of young graduates with qualitative and quantitative deficiencies in their training affects protuberantly the labor qualification with low competitiveness and very low productivity. As they swell the ranks of the unemployed people.

\subsection{Challenges of the Higher Education: The social innovation}

Colombia has also suffered the digital divide (delay) and social (poverty), internal struggles that have bled this country during the last 60 years. Some of the challenges are to achieve peace and harmony to promote social development and technical progress, the economic-sustainable development, and the economic growth with quality of life: challenges that are great in terms of competitiveness.

In recent publications of the World Economic Forum (WEF) Colombia is ranked 92 among 138 countries at science and math, so, how can we compete in globalization times?

The Organization for Economic Cooperation and Development (OECD) and the World Bank (WB), have warned that students in Colombia are passing college with serious deficiencies in Mathematics, Physics and Literacy. In order to improve the quality of the higher education (HE) in this country, these both institutions just put to the Government an extensive study in which they did 63 recommendations to the sector, such as the creation of the grade 12 for media education (ME).

In the Programme for International Student Assessment (PISA), among 44 participating countries, Colombia was in the last position, after the application of a test about the ability to solve problems of the XXI century, on 8500015 years old students, 9000 of them Colombian. The proof of the PISA, was basically an optional test of creative problem solving, in which the Latin American countries were not in any good standing in relation to other regions of the world such as Asia, for example.

A recent study, conducted by FUNDACIÓN COMPARTIR, ${ }^{1}$ focuses on Teachers, as guarantors of the Constitutional Right to Education. It has generated many expectations but many questions: Are we going to continue educating using methods and tools of the nineteenth and twentieth centuries? Obviously we believe that education is the key to face the backwardness and poverty. How to take advantage of this moment? The study focuses on the Colombian teachers and proposes their improvement to raise the quality of education. This study proposes important incentives for Educators including the sponsorship of major studies.

\subsection{Insufficiency of Research in Education}

It has been a common practice in Colciencias ${ }^{2}$ and, in recent years, MINTIC (National Ministry of ICT) that the bulk of the convocations and research resources, privilege the industrial productive sector pointing to INNOVATION, with the perverse assumption that economic growth drags the social sectors. Although it is mentioned in many documents the SOCIAL INNOVATION, in the experience, the policies and practices of the Colombian Government (GOC) indicate the opposite.

This is aggravated by the fact that all the researchers initiatives are limited to the themes that COLCIENCIAS

1 Fundación Compartir. Following The Teaching Excellence: Improving the quality of education for all Colombians (Spanish).

www.fundacioncompartir.org

2 Colombia National Institution for Science, Research and Innovation, Francisco José de Caldas. 
defines, with the detriment of the social sectors. The complexity of the HE's problems, has been focused on the poor levels of quality, competitiveness and productivity, with a high incidence in the accelerating propensity to dropout, attrition of quality, and elevated costs of the Colombian education sector.

\subsection{Competitiveness}

It is a lifelong process. Colombia is stuck in the rear positions worldwide (67th), according to the WEF's Progress world ranking; it has been disappointing, as the National Competitiveness Agenda, paradoxically has created modern institutions (one public and other private) with a multitude of isolated and unrelated policies, with little enforcement capacity and little private participation in the design of the policy. For this social Sector of Education, it is a very serious problem: is an issue of great prevalence, aggravated by the low investment in Science, Technology and Investigation (STI); the issue of competitiveness and productivity of public education is virtually unknown, although it has been claimed as a substantial element of quality and that is insufficient. The local Observatory for STI mentions that the rate of the GNP (gross national product) related to Science and Technology inversion is $0.17 \%$, which is $20-30$ times less than in the leader countries. The latter reveals a fragility of the STI sector in Colombia.

The government proclaims high educational coverage but the problem is the poor education quality which severely distorted the educational service and the labor market especially in Technical and Technological Education.

\section{Introduction: Towards a Knowledge Engineering in Education}

Knowledge Engineering (KE) in Education (KEE) is considered a part of engineering in the third millennium, that deals with the organization, representation, use and application of education knowledge to design, build and deploy intelligent agents and expert education systems. The $\mathrm{KEE}$ is considered the top step of the systems engineering and the engineering of Artificial Intelligence (AI).

The pathway to high quality (HQ) is paved with significant achievements and overcoming of great obstacles. The information macroscopic of our project is presented in Sections 3 to 7 .

In this model, the characteristics of the architecture concept are: System of Systems (SOS), high complexity, is coplanar, has concurrent and interlaced subsystems, enables several visions and approaches, and has inter and trans-organizational dependencies. [6]

The main informational components that integrate the architecture are:

- The elements related to the institutional enterprise model whose functions are peculiar to it, and are associated with the typical functions of the university mission.

- The aspects related to the management component as support.

- $\quad$ The ICT architecture.

- $\quad$ The SIFES (Management Information System (MIS) for Higher Education in FESSANJOSE ${ }^{3}$ ).

- The documentation repository.

- The infrastructure.

- The quality and self-assessment sub-systems.

We understand the self-assessment as a process and management tool, which the U. SANJOSE, with a critical review and reflection, apply into its university formation system, considering its relationships with the external sector. To achieve success (through the use of propaedeutic cycles) in a Professional Technical, Technological, and University Professional Education System, building new horizons in quality of life, welfare, equity, and social and economic development, it is required the full compliance with the accreditation regulations, the policies, and the quality assurance of the programs we are offering. Accreditation is a part of quality assurance for certifying the result of a quality assessment or evaluation.

The institutional self-assessment model proposed by the CNA (National Accreditation Council of Colombia), [13], which has four major components (factors, characteristics, variables and indicators), in turn, raises definitions such as:

- The groupings: groups of factors that affect quality;

- The variables: are attributes of the characteristics;

- The empirical referents indicators: are variables;

- The features are the model's central component; they are the evidence of an institution or program quality. The features are general and specific predicates, something that exists; i.e.: is an institution, a process, a program, or a service.

As mentioned before, in Sections 3 to 7, the mature intelligent enterprise architecture is presented: model driven, with $360^{\circ}$ vision space, accompanied by an executive survey on functional and non-functional structural aspects of the FESSANJOSE, on the road to HQ. We retrieved the best practices for HQ Accreditation that we have designed and implemented for the purpose mentioned before. Also we have developed the intelligent architecture, based on knowledge and models for the competitiveness, productivity and HQ, supported in our experiences which are discussed; the architecture engine is formed by mathematical and computational models for dynamic and structural analysis of the academic governance. Computational and mathematical models are hypotheses about reality and allow us to analyze the complex world in a more structured and coherent way. These architectures allow us to follow up the progressive enhancement in search of the academic excellence. [10] [25] [29] [31] [41] [55]

3 Fundación de Educación Superior San José, www.usanjose.edu.co. Also U. SANJOSE. 
The Figure 2 summarizes the approach we develop in this chapter:

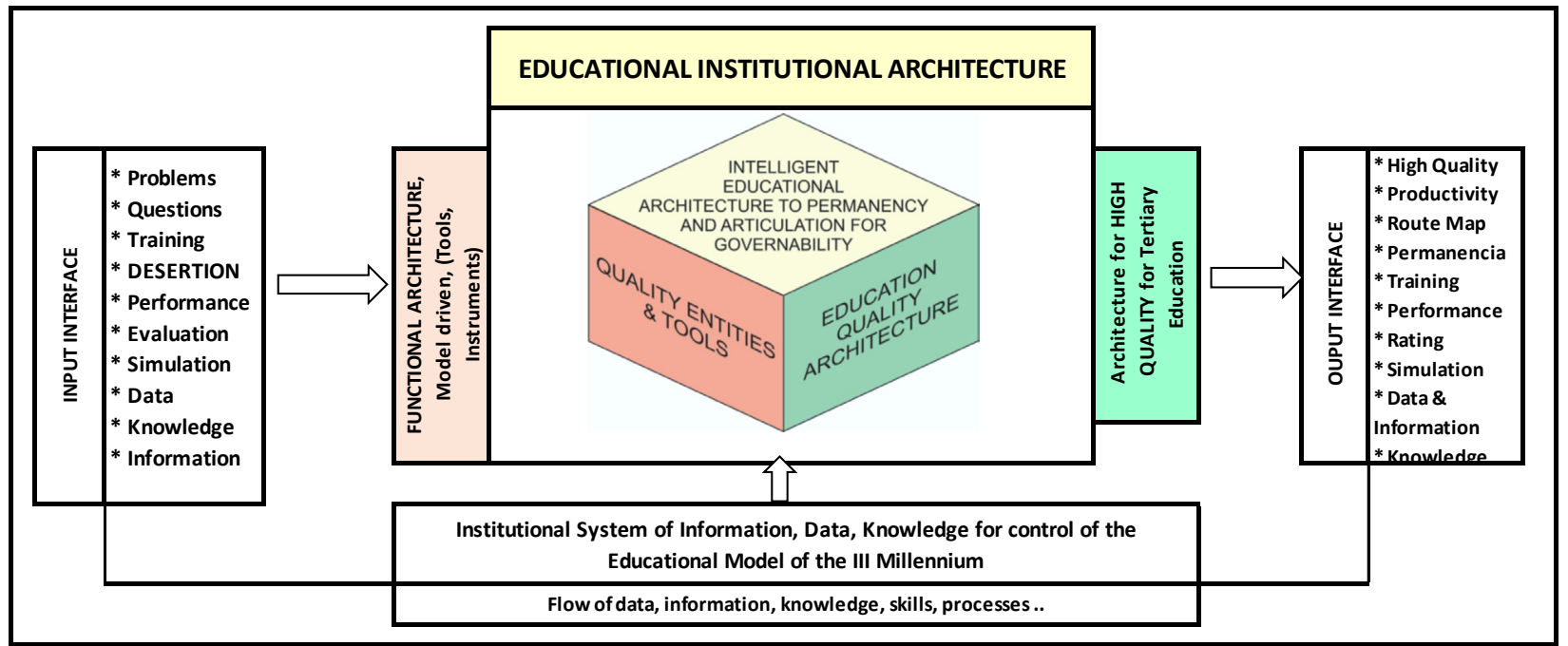

Figure 2. The 3D Architecture

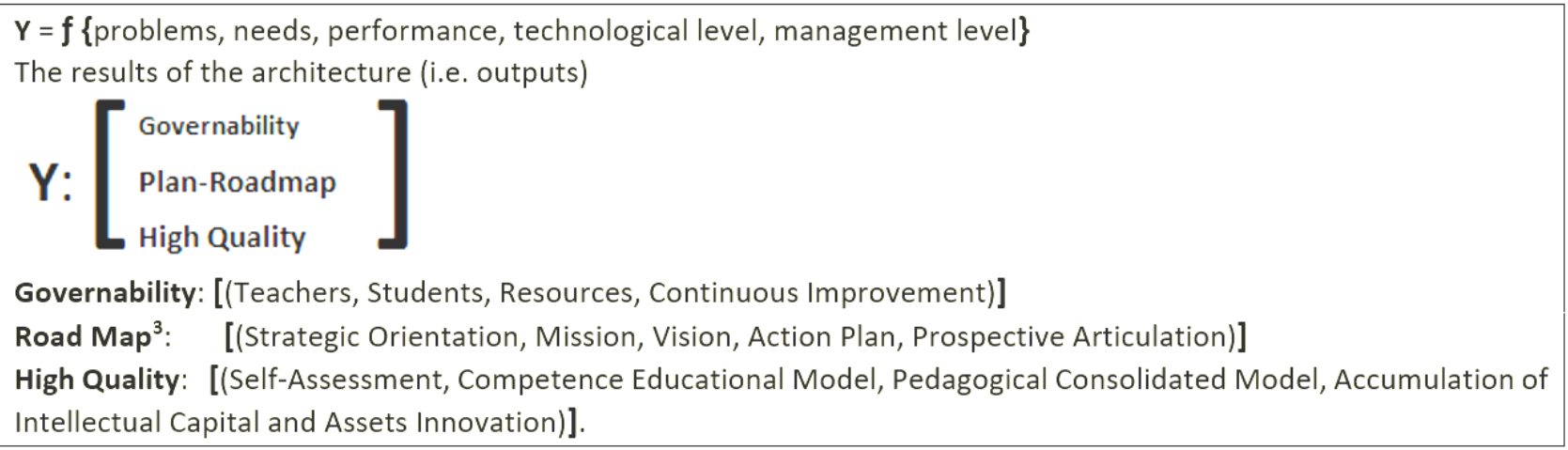

Figure 3. Architecture Computational Model

\section{Intelligent Educational Architecture}

Architecting imply the organization of subsystems or components to obtain new or better functionalities. If such components are knowledge based, we obtain an intelligent behavior.

\subsection{Space}

We developed our architecture of maturity regarding the HE problem space we used to face, as displayed in the Figure 4. The categorization of agents of this model includes family parents, students, teachers who are the kernel, the universities, the professional unions, the industry and the Government. Students and Teachers are individually represented. This architecture has allowed the knowledge mobility from it to several universities, in Colombia [34].

\subsection{The Computational Model of Architecture}

The computational representation is required for obvious reasons but is recognized the impossibility of expressing it mathematically as a determined and closed expression. The variables types involved are objects, arrays (in terms of function coverage by level and area), vector (technological level), fuzzy variables (e.g. performance management) and scalars. Their inputs and outputs give data flows simply, to express different forms usually unstructured, e.g. a problem to solve or a plan of action to follow [10] [54]. ${ }^{4}$

\subsection{Architecture Computational Model}

Architecture scheme could also be represented by a set of simultaneous equations given multiple inter and intra-relations of the system as MIS inter-temporal analysis. However the scheme described above indicates in itself, a much more rich and fertile performance to meet the

4 USANJOSE-ARQ-COHE-CURRICULAR: Arquitectura Inteligente de Conocimientos Curriculares y Competencias para Optimización de un Plan de Estudios. Registrado e implementado en FESSANJOSE, Bogotá, y en la Fundación Universitaria Comfenalco, Cartagena. Convenio 2014. HANDBOOK, ISBN 978-958-48-0412-9. Título: Compendio de Prospectiva y Planeación Estratégica con Guías Gerenciales para Obtención del Mapa de Ruta para la Permanencia Escolar en Educación Superior. 
demands of the corporate governability system, and is tending to suit individual conditions of an executive user. Then, the computer left its condition from a simple data repository and calculator, to become an expert assistant, playing a much more important role.

\subsection{Model for Student Intervention}

The knowledge based intelligent architecture has allowed us to define several intervention models for student remediation of various kinds: academic, psychological, economical, and related. The Intervention Model implies:

- Protocol for raising awareness: family parents' workshops for adapting to university life, funding for HE, sexuality, etc.

- Academic difficulties protocol: study skills and time management; tests and sensitization for teachers and students about learning and cognitive styles; and academic monitoring.

- Protocol for the prevention of depression: the Beck Inventory Test, and identification of depression symptoms for parents and students.
- Reinforcement workshops design, on basic communication and mathematics skills to be applied to freshmen students who enter to perform induction process in the first half academic period.

- Workshops design, for generating skills of texts analysis and understanding, and for basic math training.

- An integral plan: training mentoring.

- Our Architectures were included in Colombian Successful Experiences in Desertion [17].

\subsection{Lecturers and Teachers}

The widespread use of different architectures as discussed in this paper provided a space to analyze and find optimal and feasible solutions, given the high complexity of the educational sector.

The teacher side includes authoring tools for content generation, and verification of concepts and knowledge.

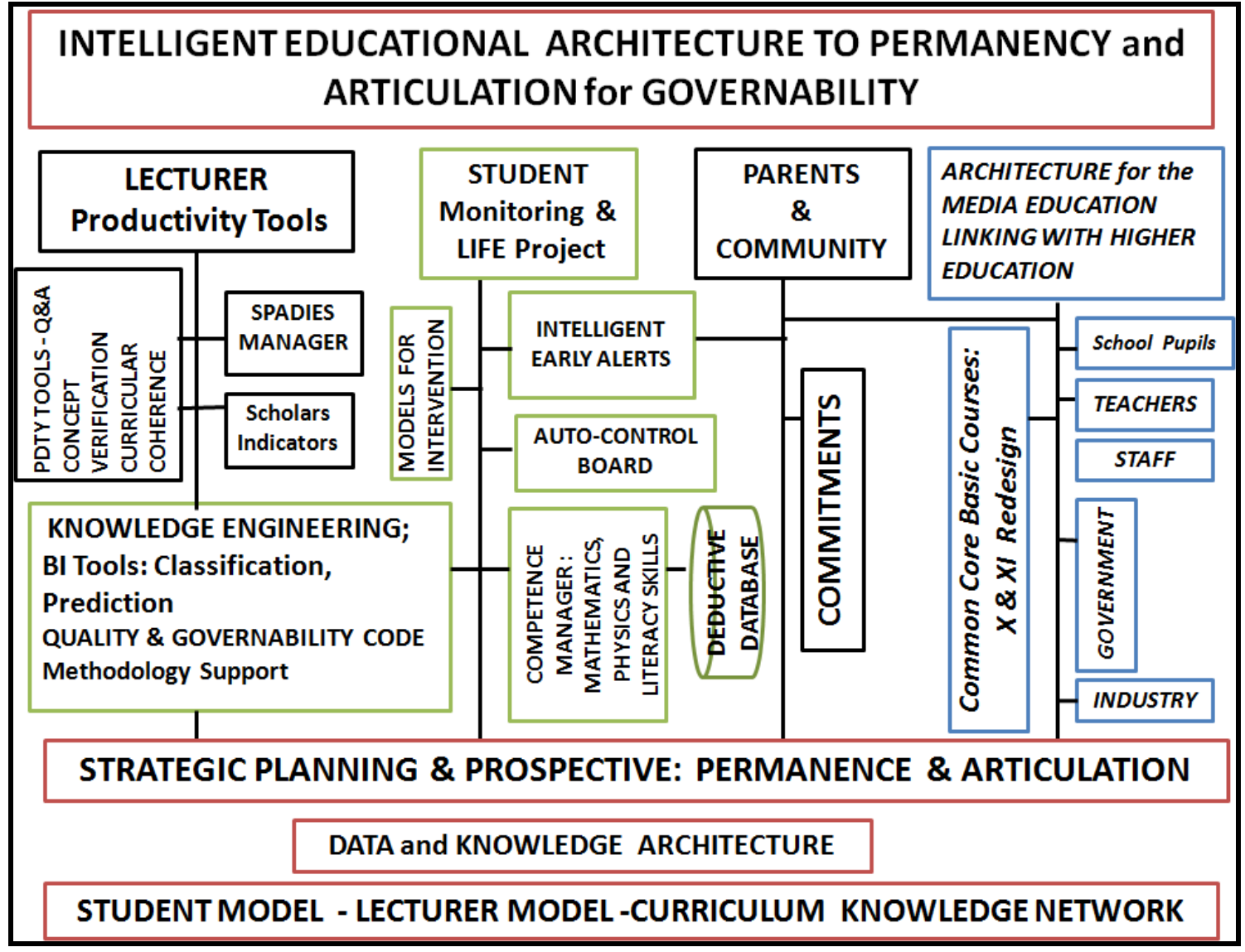

Figure 4. Multi-Agent Intelligent Educational Architecture 


\subsection{Student: Early Alerts}

The early alerts software ${ }^{5}$, for each student, approached from different fields, starting by the risk characterization of SPADIES $^{6}$ (System for Dropout Prevention in Higher Education in Colombia, developed by MEN - National Ministry of Education -) and thus, detailed tracking of students who are at high risk.

There is another area of focus for alerts regarding the attendance by teachers and students with a daily $\log$ of their assistance, which is carried out electronically, giving us an indication of both students and teachers who have stopped attending for a certain time, on the rate of absence that may promote a decline in academic quality. Other items have to do with student's academic performance and payment methods, to make an accompaniment in these respects as well.

The Model monitors students by dependencies with protocols, and determines routes, with online guides to improve Math, Reading and Writing skills, including ICT-based support and protocols for the use and monitoring.

\subsection{Student: Self- Control Board}

Student Self-Control board is a student-centered tool, to monitor his/her progress, the individual information, competencies, academic and administrative information. We constructed a Matrix prototype, regarding Objective competences vs. Micro-competences for each subject of the curriculum.

\subsection{Student-Teacher: Knowledge Engineering Tools}

Business Intelligence (BI) tools are required for mining and knowledge discovery for classification and prediction in terms of risk and desertion. It has been important for data analysis in order to improve the models for intervention.

\subsection{Competence Manager: iCOACH}

The architecture includes the design and implementation of iCOACH, which is an intelligent, knowledge-based tool, a high computing instrument to follow up each student in the academic first terms at FESSANJOSE engineering faculty, specifically in the areas of Math, Physics and Reading-Writing Skills [11] [54]. The software architecture has 3 main parts: Edumatic Builder (as productivity tool for the Teacher with competence manager), the Student Model, and the knowledge base for concept verification. Several previous works have preceded this project, so our methodology and related knowledge are very experienced. A prototype was built [25] to demonstrate the iCOACH validity and applicability, and as an academic productivity instrument for competence management. Below is a scheme of our Knowledge competence manager we are working on:

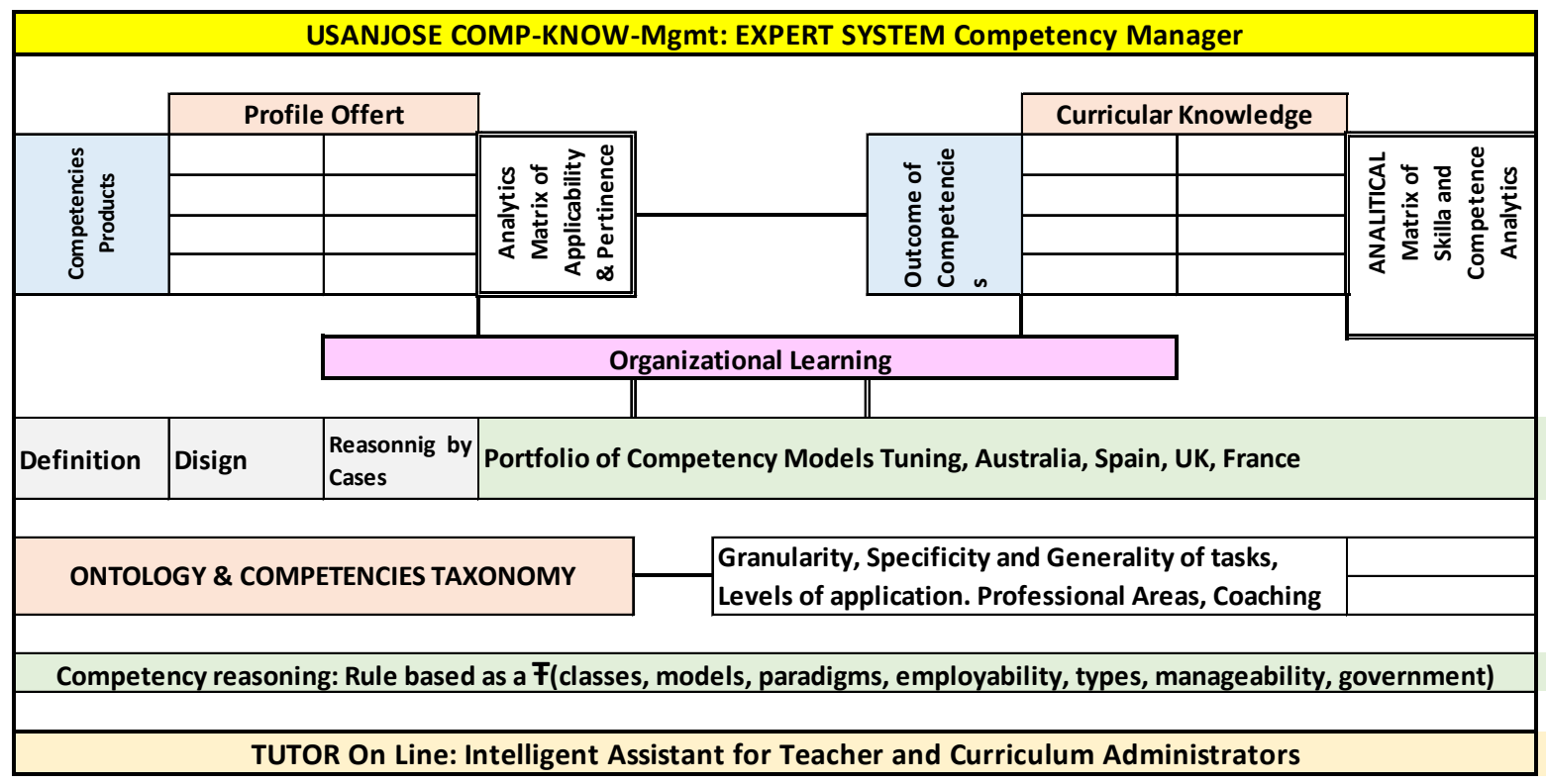

Figure 5. Expert System for Competencies Management

5 07/01/2014: USANJOSE ADVERTOR-HE. Software record, registered Book 13 - Volume 41, Part 203; DNDA, Colombia National Directorate of Copyrights.

$6 \mathrm{http}: / /$ spadies.mineducacion.gov.co/spadies/ 
The USANJOSE COMP-KNOW-Mgmt Architecture is an EXPERT SYSTEM as a Competencies Manager: It allows entering needs to obtain guidelines for the teacher that help in the design of competencies and micro-competencies. Its final purpose is to contribute to the organizational learning as follows:

(1) The Relevance Matrix allows to reason on the relations between results (profiles) and the objective-competences to obtain.

(2) The Competence Coherence Analytical Matrix makes it possible the reasoning about the relations between objective-competences and the micro competencies of specific curricular training plans.

(3) A classification of models and COMPETENCES systems is required, through ontological reasoning, to explain Granularity, Specificity, Generality, tasks, Levels of application, Professional Areas, Coaching, and others.

(4) Including The Competent Reasoning Rules System: Rules $\mathrm{F}$ (classes, models, schools, employability, types, manageability, and government).

(5) And with TUTOR: Smart Assistant for the Teachers and Curricular Managers.

\subsection{Linking ME \& HE}

There are various kinds of Articulation between processes, cycles and levels of education, and between these and Industry, Government and Society. The most serious problem is the articulation of ME with HE.

Also there are other complications: how is the joint of educational coverage with the quality of education itself; and the articulation between the propaedeutic cycles in union with the integrative skills that are promoted, from the basic to the disciplinary.

Similarly, we could try other extensions as: to articulate quality educational excellence, articulate the dimensions of the productivity, and the quality and competitiveness of the education sector (which requires relevant education) to reach an ongoing process as a mediation to articulate the Information Society with the building of the Knowledge Society in that leading countries are engaged.

It has been a constant and ongoing activity to improve student's skills in math, physics, and reading and writing, which allow high school attendees to enter HE and show success in curricular flexibility, and a substantial improvement in the State tests results. This component allows students in high school institutions to have articulation agreement with the University, to access 3rd semester once they have completed their ME.

\subsection{Prospective and Strategic Planning: A tool for Future Analysis}

The STRATEGIC PLAN articulated with the Prospective, allows to define the roadmap to align human, physical and technological efforts toward HE Competitiveness, comprising: SWOT matrix, Critical Success Factors, Strategic Orientation, Strategic Map, Prospective and Scenarios, Desertion, and Addressing ME-HE Articulation.

A major product is a Handbook of Quality and Governance in Student Drop and Permanence, including the definition of institutional policies [39].

\section{Enterprise Information Architecture for HQ}

\subsection{Architecture Justification}

The Architecture is the statement towards the system determination and development, which is appropriate for the problems of $\mathrm{HQ}$ and competitiveness, and is the communications channel between the involved agents. It facilitates planning, management and execution for the University's strategic development. It can also be seen as the expression of persistent characteristics and principles that support the HE system to guide acceptable permanent changes.

Architecture enables verification and comparison about whether the implementation of academic and administrative system is in accordance with the architectural description. Many innovations have been the result of our careful study and insight at the architectural level.

Generally the university enterprise architecture is composed of Strategies, Academic and Organizational Processes, Human and Technology resources, Intellectual Processes, infrastructure and other architectures. It enables the coherence and consistency among architectures.

\subsection{Information Architecture Description}

As started in the introduction about the architecture integration, we have these main informational components:

(1) The elements related to business enterprise model, which functions are linked to the functions that are typical of the university mission.

(2) The component that allows access to Institutional and Strategic Plans for each Academic Program, and the Intellectual Assets as Production: Papers, Books, Software; i.e. SIFES $^{7}$, etc.

(3) The aspects related to the management component as support for the internal and mission processes.

(4) The ICT architecture: PLANESTIC, and the VIRTUAL Self-Assessment Program

(5) The MIS (SIFES): functionalities, their MODULES and Documentation; the architecture for early warning; FESSJ-ADVERTOR and ME-HE LINK; and knowledge mobility with other institutions in Colombia ${ }^{8}$.

7 FESSANJOSE MIS for HE (Spanish) intellectual active.

8 Universidad Tecnológica Del Choco, Agreement 0071 2013; Joint to 
(6) The quality and self-assessment architectures, which are discussed later.

(7) The Documentation Repository Center: Government and Internal Regulations, the whole academic programs Master Documentation, etc.

(8) The infrastructure: Computer Technology, Facilities, Buildings and Labs.

\section{Institutional Self-Assessment}

\subsection{Regulations}

The gross guidelines have been given by the CNA of the Colombian MEN. It should be noted that the full compliance with the accreditation policy and quality assurance programs we run, emanate from the Law 30 of 1992, Law 1188 of 2008, Decree 3462 of 2003, the Guidelines for Undergraduate Programs Accreditation (January 2013), and the resolution of Initial Conditions, 002 Agreement, in April 2013 from the MEN, among others.

\subsection{Description of the Architecture of the Self-Assessment}

The institutional Self-Assessment model proposed by the CNA, has four major components:

- Factors between 8 and 10, which are groupings that affect quality

- The features 40 to 42 are measurable properties which are the model features component, expression way of an institution or a program quality. These are general and specific predicates of whether an institution is an academic or organizational process or a service. For example in the Student factor, features are: 1. Mechanisms of Selection and Admission; 2. Admitted Students and Institutional Capacity; 3. Participation in Integral Formation; 4. Student and Academic Regulations.

- The aspects 181-243 are relative values associated to empirical variables. For, the item 1 , mentioned above, the aspects to investigate are: 24 Special requirements to admission to programs that merit it; 25 Admission Policies and exceptional mechanisms that are made public; 26 Profiles of mechanisms supported by exception; 27 Systems and evaluation mechanisms and processes of admission and preselecting, including the implementation of this Assessment results; 28 Admitted to each admission processes of the last four cohorts, by application of general rules or by applying exception mechanisms.

- The quantification mechanism is carried through online surveys and oriented interviews administered to all involved actors (students, administrators, teachers), and by the data and information systems analysis, on the University or the Government institution.

In this information enterprise architecture, we developed a Scalogram Multivariate Matrix with fuzzy values for self-Assessment (degree of completeness): The size of the Self-Assessment matrix for one year is 230 rows (aspects) by 45 columns (academic and administrative process). We evolved the matrix from a qualitative model to another with metrics as we applied the same methodology of the curriculum coherence architecture, a previous work. The well-known AI process known as desfuzzification that we have used on many occasions can quantify the self-assessment. In the next future we may extend it to inter-temporal analysis.

\subsection{Objectives of Self-Assessment}

The objectives of self-assessment are:

- Set the quality to Imperative

- Generate the continuous improvement processes

- Create an open thinking for the change: the Society's own knowledge

- Project the new and improved academic and administrative processes

- Assess and maintain the internal and external customer service (students, teachers, parents) quality

- The continuous improvement of developing plans with national and international visibility

- Unify the processes and procedures effectively and efficiently with productivity.

- Determine the Self-assessment as organizational processes (academic and administrative) to integrate it within the Processes Matrix for optimization purposes using our knowledge architecture.

- Analyze and evaluate information in a well-structured $360^{\circ}$ Vision way, which the architectural approach allows us to do.

- Equally, to browse the entire University administrative and academic information (walking-through: top down and bottom up).

- Greatly, by the applied method, facilitate the strategic alignment of the different units, with the final strategy: the High Quality.

- Through the information congregation, reduce the complexity of the analysis and design of coherent institutional improvement plans.

- In the Self-Assessment managed as an organizational process, facilitate organizational metrics using the linear programming and Leontief input-output models (which extend its value).

- Integrate the self-assessment as a process variable, i. e. allowing to quantify the Self-Assessment incidence in terms of quality, academic sustainability, student desertion, and many others. 


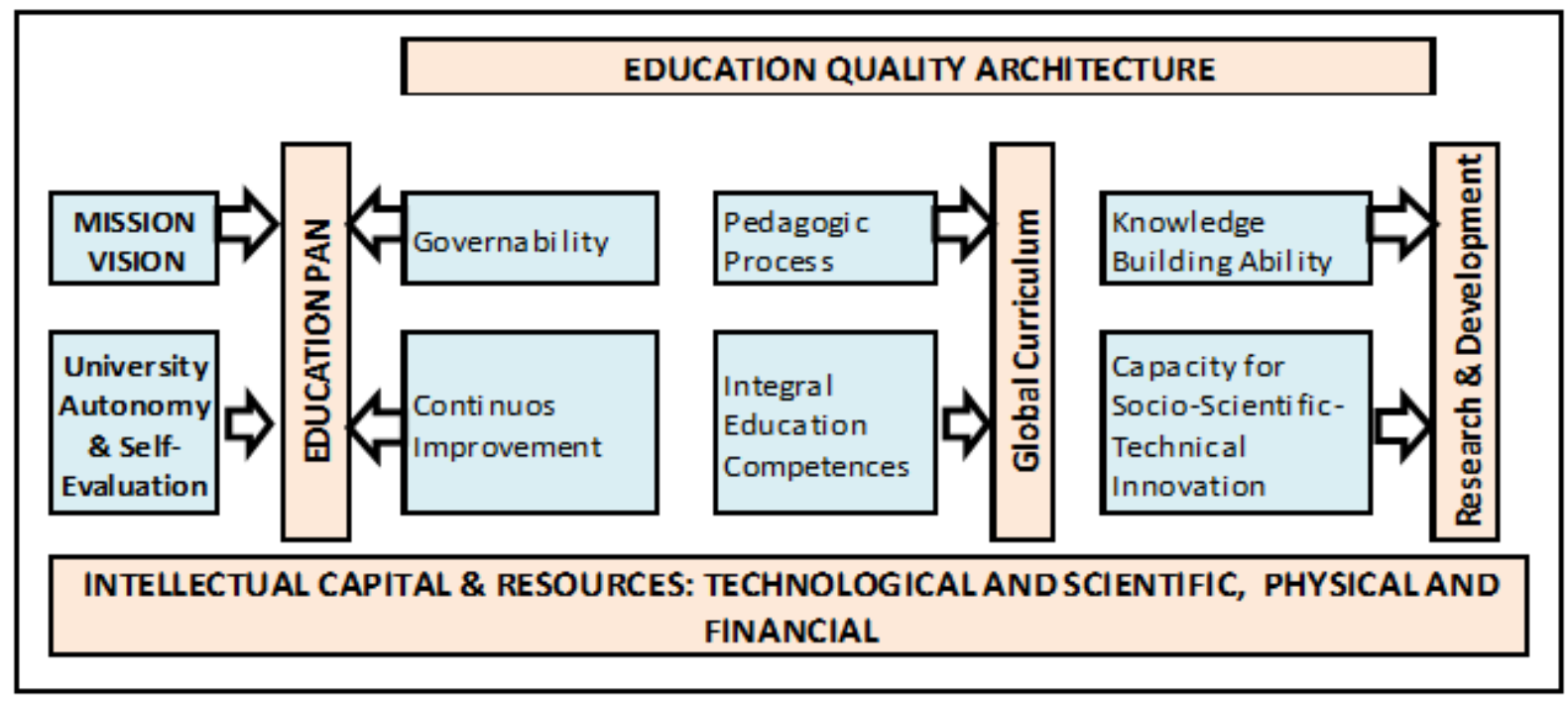

Figure 6. Quality Architecture for HE

\section{High Quality in Tertiary Education}

\subsection{The Quality Architecture}

Quality has its ethos in a HE institution (HEI). The accreditation of HQ is the completeness verification of the whole institutional quality, which has many different sides and is a complex problem to determine. It is a system whose components are integrated flexibly towards educational excellence. The self-diagnose, the current state, allows to determine the distance to perfection limit. The HQ of the HE is necessary but not sufficient to achieve the sector competitiveness.

These innovative developments have been the result of a long processes of submitting to the education authorities, all our programs, including 3 educational levels (Professional Technician, Technologist, and University Professional), and several areas (Engineering, Business Administration, Design and Arts, and also Sports); in total, more than 30 programs in the last 6 years, with accountability to education authorities and with rigorous academic peers, to meet the quality standards for obtaining the Qualified Registry, as required by the MEN rules in Colombia. Also there is our outcome of huge experiential learning as Academic Pair with the National Intersectional Commission for Quality Assurance in Higher Education (CONACES) and CNA [13] [15] [23].

The Quality Accreditation (QA) has four main components, in our way of looking:

- Educational Plans, which define the Mission and Vision horizons: the use of the university autonomy accompanied by self-assessment; the governability that focuses on the feasibility of making the necessary decisions; and the continuous improvement (See section 6.2 , bellow).

- The global curriculum typical of the knowledge society and the educational opening with modern educative process, which is focused on the student learning personal autonomy and on competence-based integral education. One of its components is the In House Internationalization. In FESSANJOSE we started this process several years ago. Nowadays we have the MEN support and accompaniment, with the most important universities like La Salle and Rosario. Also recently we have the mentoring by representatives of the University of Yale and the Kentucky State University inside the International Mentoring Program provided by the MEN. Accreditation could be an important tool to enhance and improve cross-border education. The term Accreditation describes the process of certification and the result of it, as mentioned before.

- Research and Innovation to develop the capacity to produce knowledge and innovation. The knowledge architecture is discussed in Section 6.5 (bellow) that allows us to quantify the knowledge production and also the accumulation of Intellectual Knowledge? .

- The infrastructure refers to the required intellectual capital and knowledge assets, the financial resources including technological ones, and total quality: from the beginning to the end in the pursuit of the excellence.

\subsection{GOVERNABILITY: Knowledge for All}

The integrated architectures and models for the knowledge society promise to be a tool for analyzing and quantifying the HE Competitiveness in this country, with the best potential for HQA by the HEI. [18] [21] [48]

The above highlights the methodological framework for

9 Our knowledge production can be seen in www.Colciencias.gov.co San Jose International Research Group -Cod 0084828- We were recognized in 2010, classified and categorized in 2014, by COLCIENCIAS: Colombia National Institution of STI. 
learning and prototype development which allowed us to identify problems and provide answers by the same engineering rigor, and summarizes our research efforts, that propose solutions which combine intelligent virtual environments both as a computational and mathematical model for the purpose of providing systemic answers to the problem of dropout and repetition in HE.

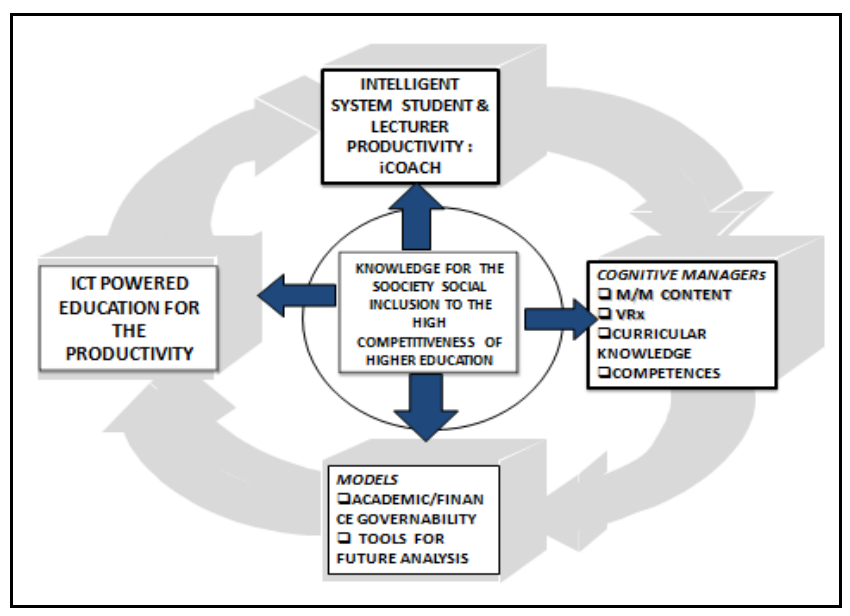

Figure 7. Knowledge for All

\subsubsection{Governability}

It is a concept that goes beyond what an administration is and is associated with the conditions of the institutional capacity to deliver the educational goods and services, the ease for decision-making, the management of the new intellectual capital, and related, to meet the needs of government, business and society in general.

It is affected by the overload of demands and social requirements, and by factors such as the trust, the participation and the consensus building. University Governance and Financial Sustainability are closely associated. They are not a matter exclusively of educators neither the sustainability is a purely financial issue, but finance is a strategic component of the strength of educational institutions.

A model of corporate governance is the composition: consistent, coherent, concerted, committed, participatory; and is assumed by the set of systems and actors, about ways of thinking, decision taking, acting and learning, that shows an Institution in the different dimensions of its strategy.

Also the governability problem is related to mobility of students between the cycles of formation and the levels of productive sector as well as the establishment of a TP (Professional Technician) - T (Technologist) education with international competitiveness and quality.

\subsection{Continuous Improvement}

This architecture is not a simple conceptual and methodological improvement, but an innovation in the comprehensive and coherent treatment of the concurrent problem Desertion-Permanence-Repetition-Quality, in two ways: in the use of creativity in the analysis of problems and the use of creativity in solution of problems. One consequence is the possibility of dynamic analysis, as illustrated in Figure 8.

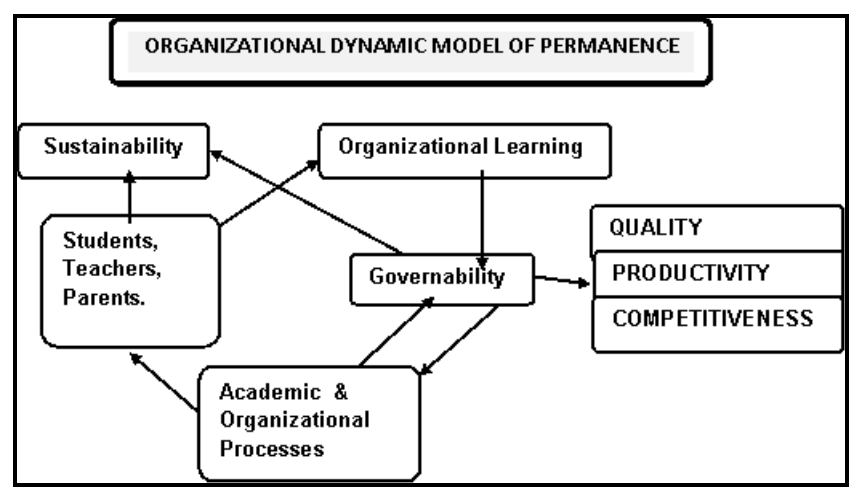

Figure 8. Permanence Dynamic Analysis

The model focuses on organizational governability with its impact on the financial sustainability, knowledge generation and institutional learning (starting from Young Seed Research Groups) to QUALITY, PRODUCTIVITY AND COMPETITIVENESS. The core mission focuses on student productivity (supported by an intelligent system), teacher productivity (supported by an intelligent handler of competencies and an intelligent courses-contents generator, and also the system for coherence curriculum optimization ${ }^{10}$ ).

\subsection{Pedagogic Model and Integral Education}

\subsubsection{Pedagogic Model Description}

In strategic alignment with the IEP (Institutional Educational Project), the pedagogical model promotes the development of multiple intelligences to develop during the preparatory stage of cycles as axiological aspect of the subject in his/her student LIFE PROJECT.

It encompasses the strategy and pedagogical decisions rules which are an important component of the institutional navigation chart, the IEP, and more specifically, of the aims and objectives for strategic processes and action plan, focusing on skills training for evaluation and permanent control. [30] [46] [54] 


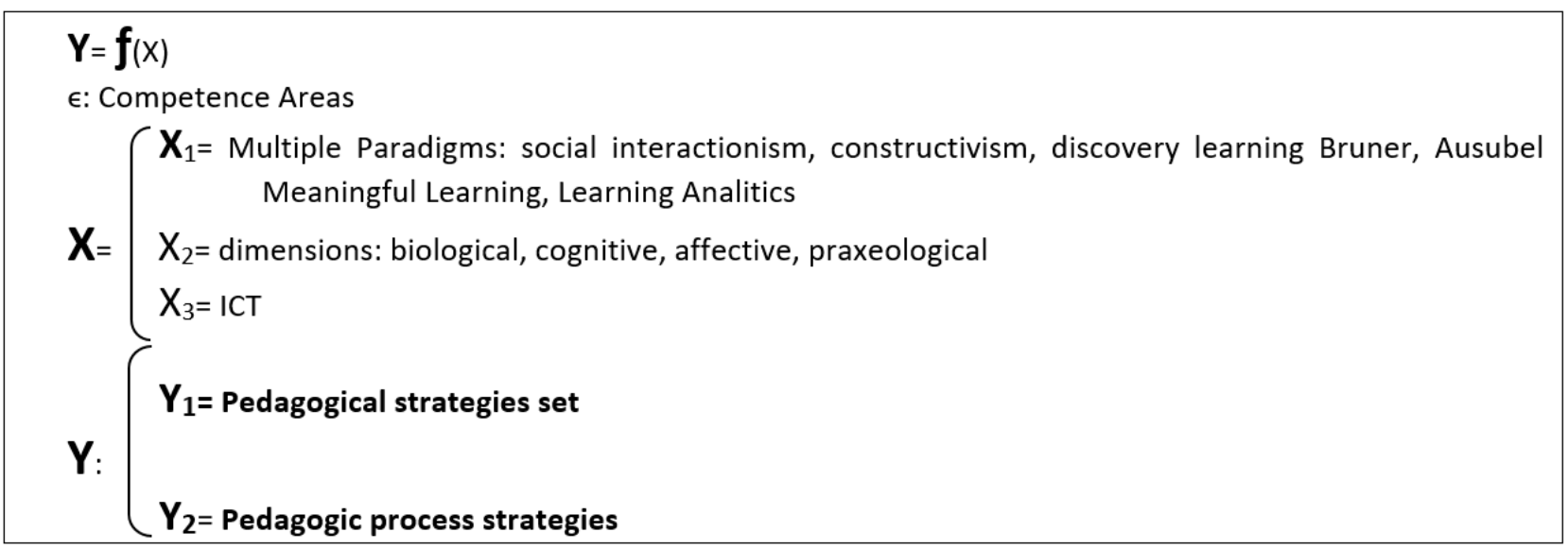

Figure 9. Pedagogic Computational Model

A pedagogical model is part of the corporate strategy, drawn on pedagogical mediation by ICT and the support of the new learning theories in virtual environments known as computational matetics (from Greek manthenein $\mu \alpha v \theta \alpha ́ v \varepsilon ı v$ : to learn). The Consolidated Pedagogical Model promotes strategies that are required for the design and implementation of the whole pedagogical processes inside the HEI.

The FESSANJOSE's pedagogical model is configured from its constituent principles, which correspond to the following, regarding the conception of the subject (person), and the training:

- It is framed within the features of Colombian Education Law

- It is established by the conceptions of the person from the perspective of the integral education

- Under the vision of the documents, the four pillars and the seven lessons for the future education of Delors and Morin [28], the ones we provide in relation to the conception of education.

- About the conceptions for the project life skills, profession, education and communication.

- From the perspective of social inclusion, human development and welfare.

- In connection to educational and pedagogical concepts: the developing skills to generate meta-compressions and understandings from the reflections.

- From the question as education strategy.

- Through the significance of meaningful learning experience.

- Through interaction in teaching

- From the perspective of the person's intelligence under the multiple intelligences look.

- Through understanding the pedagogical models.

- Located epistemologically, and practice, in the constructivist model.

- Through strategies and active classroom participants.

- From the problem solving perspective.

- From projects generation that facilitate learning through the acquisition of knowledge and problem-solving situations.
- Through the interactions of the subjects (teachers and students) and the relationships established and recognitions achieved.

\subsection{Knowledge Architecture}

\subsubsection{Conceptualizing}

The Knowledge architecture can be defined as the set of strategic design decisions that affect the structure, intelligent behavior or functionality of the system as a whole. The HEIs are the natural space where the ethos of knowledge can be developed and the Intellectual Capital (IK) can be accumulated. It's no secret the inadequacy of the MIS to incorporate knowledge. In fact it's shared by many authors that well over half the market value is explained by the IK in companies of the Third Millennium. Traditional systems do not account for the IK and only estimate the in book values vs. market values, when selling focused on negotiation processes. On the other hand, there are already quite a few financial models of the knowledge economy that consider the IK. For the universities it's a critical issue in the way of the HE competitiveness.

\subsubsection{Knowledge Process}

A process is defined as an activity that takes place in ongoing stages to produce a result or a specific group of them coherently. It is a set of activities that transforms inputs into a product or a service with customer value.

A knowledge process is a sequence of iterative activities characterized by having measurable inputs/outputs and value added activities, including organization, staff, equipment, procedures and materials required to produce a result: knowledge, intellectual assets and intelligent performances.

\subsubsection{Educational Innovation or ICT Innovation?}

It's unanimous consideration that practices have not been technical or scientific change had no impact on pedagogy. The education sector has been profiled in two ways, sometimes contradictory: a changing and modifying way, 
since the education sector has to educate future generations with the scientific, social and technological changes, and the other, the conservative way, given that it must preserve the social and cultural structures, which favors.

But it is also noted that, behind, are the benefits of such changes. In these days of rapid obsolescence, is when the education sector will require more innovation, and is when to take advantage where possible, from developments in other sectors, besides, enabling the transformation of knowledge appropriation practices from different compartments of science and varied cultures.

The question remains whether the innovative activity in computer science education should be the set of social research, i.e., the progress of scientific basis, or else, its origin is in the progress of computers according to the possibilities of profit to be contemplated. [30] [43] [51]

\subsubsection{Mathematical Knowledge Architecture}

The Mathematical Knowledge Architecture comprises the Leontief Input-Output matrix (innovated to the knowledge Society) in a system either at the micro level (i.e. a program of study) or a higher level of an institution or a country. This architecture has 3 components:
- The inter-sector industry subset, including the Knowledge Sector

- The restriction and threshold values: real world facts.

- Various objective functions.

The model was integrated with linear programming to analyze together the Education services in the Tertiary Sector of the economy (trade and services), with the primary sector and the manufacturer sector.

The optimization criteria are shown schematically in Figure 10, which shows the levels of students in HE related to permanence/desertion.

The governability deals with the control of the flows within these levels of students, outlined and quantified in the multiple objective functions. It seeks to maximize the number of students performing well, given the facts of the HEI's world (restrictions, limits) which is one of the indicators of quality, pre excellence. The academic governance also implies the control flows that are contrary to policy optimization. The model also generates information on the flows of students' costs.

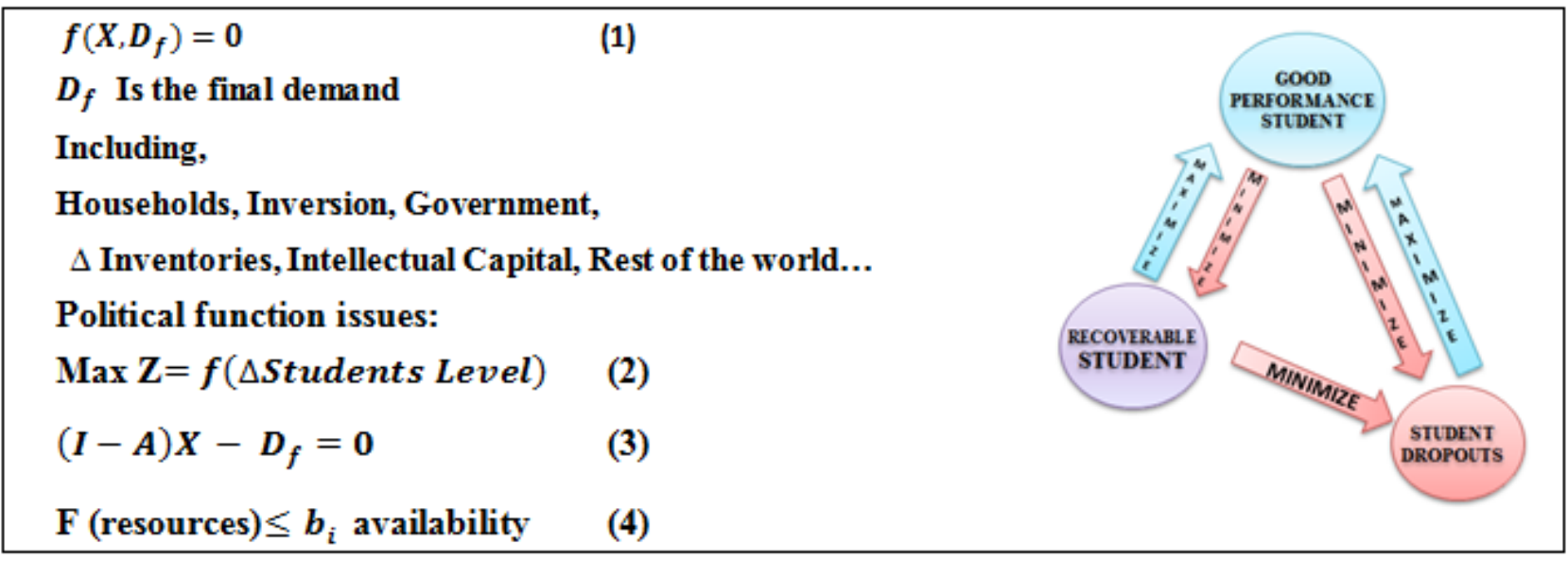

Figure 10. Computational Model

\subsubsection{Strategies Analysis}

Among the questions that can be analyzed and quantified running the knowledge architecture would be:

- What would be the cost of changing a student from one level to another?

- What would be the opportunity cost of losing a student from a higher to a lower level?

- What management strategies of economic, academic or pedagogic types, respond better in order to maximize the number of students who leave school?

- Which strategy is more responsive to the maximization of repetition avoided?

- How an institution responds to the demands facing in improving the economic and curricular quality and competitiveness without breaking?

- How much does it cost for an institution to improve its quality and competitiveness?

- How is the cost of the Internationalization process?

- How much does it cost for an institution to improve global competitiveness?

- What additional financial and technological resources an institution needs to maintain good government?

- What is the value of intellectual capital accumulated in a university? 
6.6. Architecture Synthesis

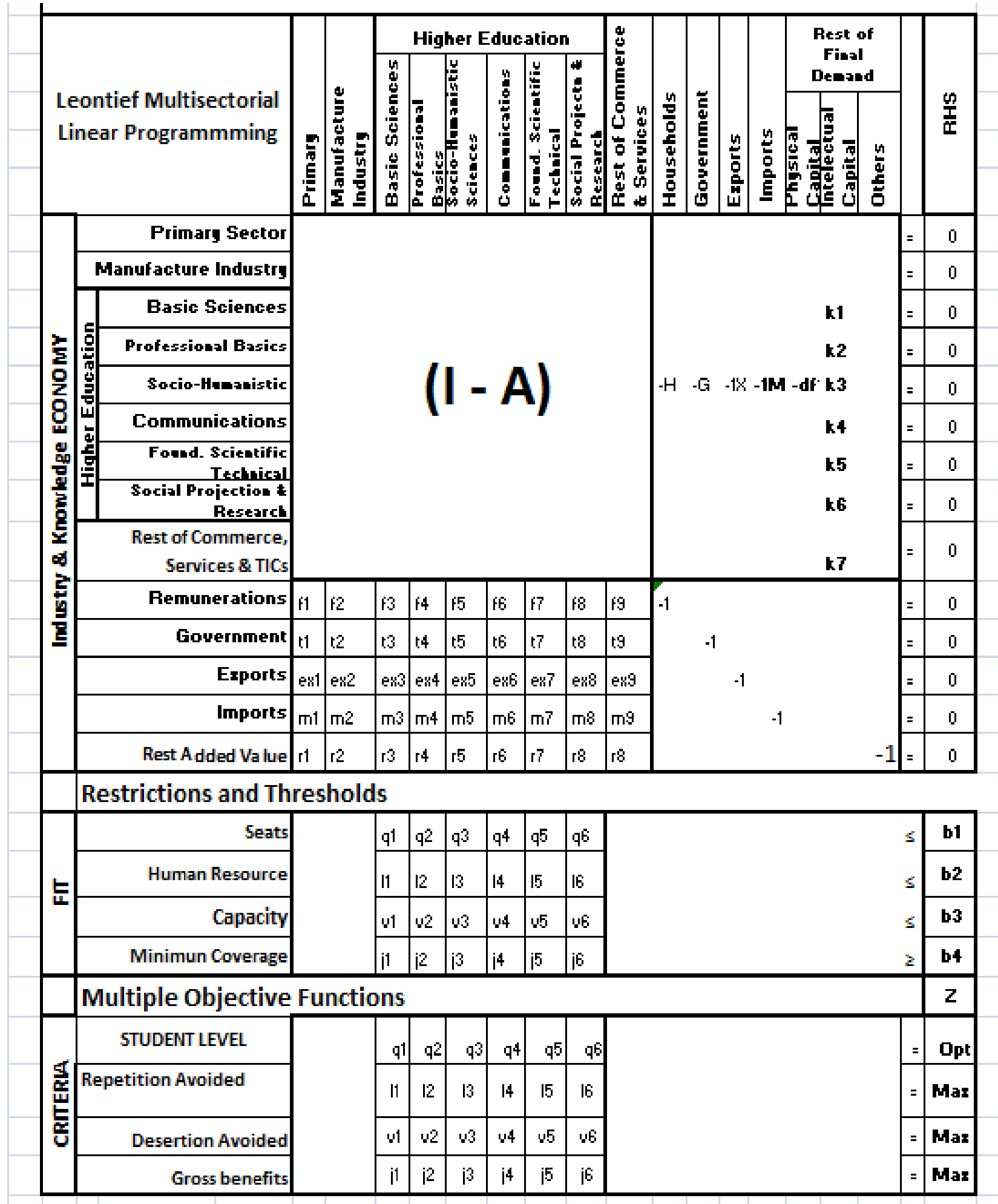

Figure 11. Leontief Model with Linear Programming 


\section{USANJOSE-ARKE-INTELL: Institutional System of Information, Data, \& Knowledge for Control of the Educational Model of the III Millennium}

As said, a new intelligent, competences-based educational model of institutional software architecture, seeking a ME HQ, is offered. See Fig. 1. A previous advance [3] was submitted to EDUCON 2016.

\subsection{Description}

A multidimensional approach was adopted. The first dimension is related to HQ [38]. The second is the dimension of the iMIS (Intelligent MIS), as described in Section 3. The third, deals with the architectures described in Section 4.

The strategic development is based on social innovation with KE.

Intelligent Coaching contrasts the universe of thematic skills with the user acquired skills, by checking concepts and expertise with intelligent, dosed, classified, and oriented questions, to test knowledge and skills, with individual self-regulation and cognitive control. Remediation is done through online platform or optionally with an accompanying teacher, or a mixture thereof.

We estimate at more than 3 million the users for this project, which is under construction for the next three years.

\subsection{Characteristics}

- The deployed architecture illustrates a MIS complex whose components articulate coherently and consistently acting as an organized whole, to obtain new and better functionalities.

- The architectural approach has been analyzed and evaluated with large volume of academic and administrative information in a well-structured way, with $360^{\circ}$ visualizations. We also allow to browse administrative and academic information from the university in upward and downward directions, and also over time (Prospective) for constructing future.
The gathering of information at different levels of aggregation will reduce the complexity of the analysis and design.

- The strategic alignment of the different components has provided the ultimate aim: HQ. It has provided the harmonization of academic and administrative processes, and the establishment of common references for the community in accordance with the International Organization for Standardization, ISO. Obviously we have also included the alignment of micro-competences with the target professional competences of academic programs.

- Continuous improvement plans will provide coherently leaning, mature, academic and management indicators as subsystem for inferences in strategic planning and prospective.

- The Self-Assessment, as an organizational process, has been facilitated by metrics inside the linear programming with the Leontief Input-Output model, which extended its value for optimization purposes, towards governability. This governance is based on maintaining the maximized number of students in good performance, and also on controlling the number of students at risk of dropping, and recuperating the former deserter students. The Self-Assessment model for HE is in accordance with the CNA, for which some tools to managing large volumes of data and visualization are used, through a multivariate Scale-gram: matrix with fuzzy value (qualitative) variables.

- The system follows an asynchronous methodology with competencies certification by levels, supplied by our University.

Our work has attempted to fill a gap and to be a response, in which we have worked with scientific rigor and discipline. Our implementations have proven to be useful for understanding the reality of the $\mathrm{HE}$ and for the transformation of the sector itself, which facilitates the entry into a knowledge economy.

Thus the mathematical and computational tools make the decision making and also the definition of policies easy, in a way more than proportional. This is the iMIS CONTROL Information we called USANJOSE-ARKE-INTELL: 


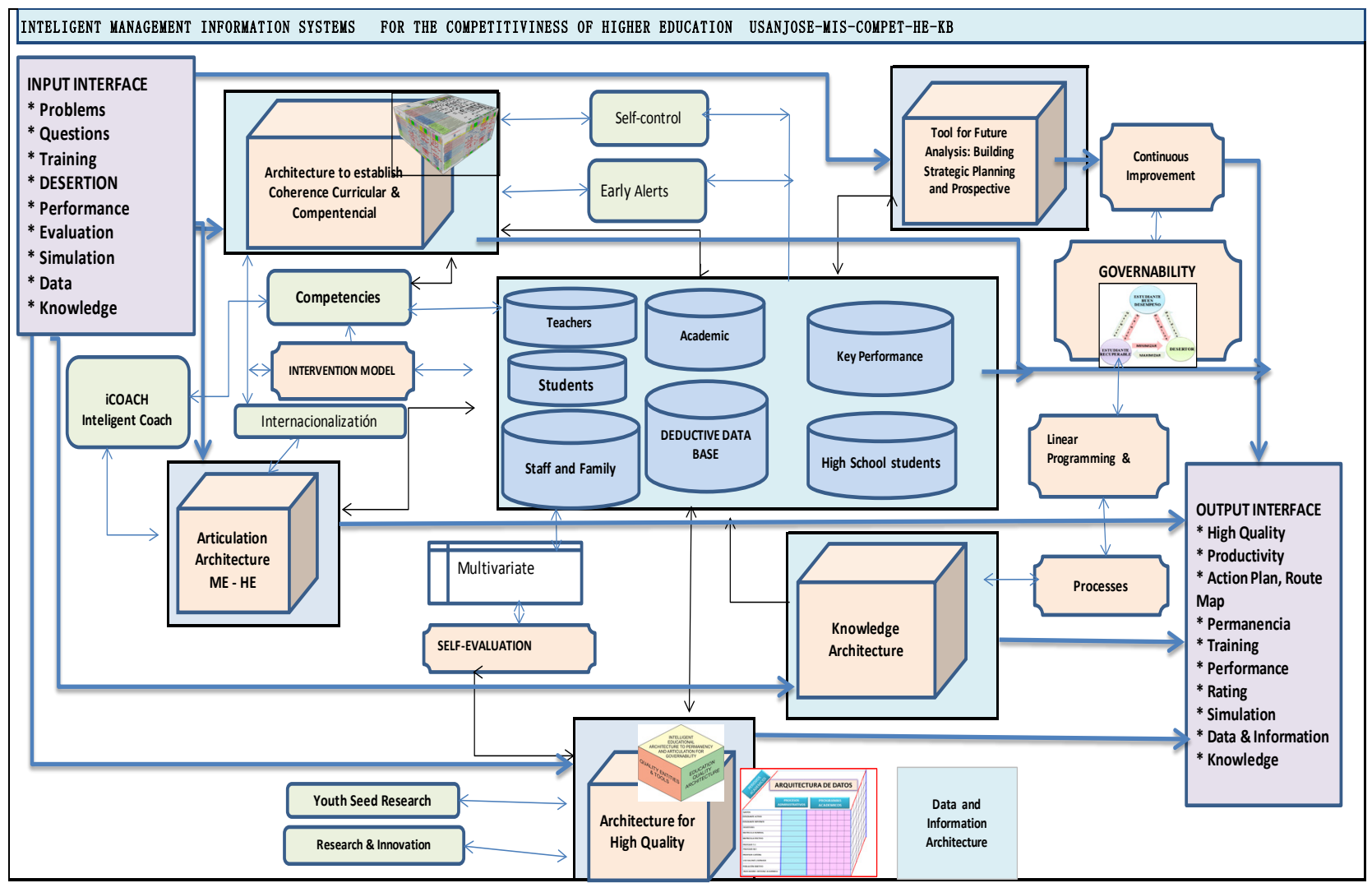

Figure 12. USANJOSE-ARKE-INTELL, flow of data, information, knowledge, skills, processes

A previously developed MIS ${ }^{11}$ is the "Intelligent Information Management System by Architectures in Higher Education for Academic and Administrative Management" (Spanish). This paradigm is considered as the systematization of human intelligence, a substitute to human reasoning, and also as the foundation of intelligent reasoning in order to encapsulate solutions to difficult tasks and problem solving skills, to face the complexity of higher education. For adaptation and evolution in the modern university, the governance, the teacher and the student productivity are combined with quality education. 


\subsection{Components}

- The Input Interface: is for the data, information and knowledge acquisition, where the attributes, parameters, values, problems (e.g. desertion) in active and dynamic structures, are obtained and recorded. The problem is expressed as the kind of decision making problems, i.e. the complexity of the desertion information needed: students trained in math skills, a survey about the system variables, and ratio of decreasing levels in the current gap between the actual state vs. excellence.

- Databases and knowledge level (deductive databases): are about the students at risk of dropping out and the possibility of identifying new knowledge from the deductive database, as e. g. characterization of student.

- Coverage: involves functions at management level and/or academic abstraction (semester, program and area, covered by iMIS), e. g.: Registration and control, Accounting, Finance, Human Resource, Stores, Educational Services Laboratories, Students, Parents, the MEN, and others involved.

- $\quad$ Performance (Output Interface): refers to the inferred or explicit management skills in terms of quality and academia.

- Decisional reasoning in several domains: organizational and/or academic information processes required for making decisions based on quality and user level. Involves MEN standards, and also the determination of mathematical and non-mathematical instruments (e.g. econometrics, statistics and computer organizational culture of the institution).

- The levels to implement are: The I/O interfaces, complex architectures, models, databases, and applications in the field of HE. Y(MIS) $=f_{\text {technological level, management level, plan-user, Training }\}}$

FUNCTION Y(MIS) represents the output or results of iMIS, such as quality metrics, management indicators and values, defection, answers \& plans, required knowledge, solutions, inferred plans, policies and continuous objects improvement for the sustainability of quality, among others.

\subsection{Architectures of USANJOSE-ARKE-INTELL}

The iMIS integrates multi-hybrid system architectures as a space to meet the problem solving aimed at a competitive HE, specifically noting how they can include these new technologies.
There are 5 architectures:

- Academic productivity for curricular analysis, management and optimization.

- Student productivity with intelligent coaching.

- Building management technology: construction of the future: roadmap for student permanence.

- Institutional productivity, process engineering for governability.

- Quality management, for HQE.

In Figure 13, these 5 architectures are shown, most of them have been implemented in several HEI [16] [37].

\subsection{Academic Productivity Architecture}

USANJOSE-CUR-COHERENCE-ARCHITECTURE ${ }^{12}$

"Intelligent Architecture of Curricular Knowledge and Competencies for optimizing a Curriculum in Higher Education". This construct is one of the previous work [39], one of the results of a research project, that has been implemented in several institutions in this country and duly inscribed in the DNDA (National Bureau of Copyright). The curricular coherence architecture is a linear mathematical and analytical tool of academic information, enabling the curriculum making sense as a whole complex. Academic coherence refers to the logical-cognitive relations between parts of an educational system architecture. It's an analysis instrument which provides optimization for an engineering curriculum using propaedeutic cycles, and weaves the coherence and consistency, both internally and externally.

The curriculum and competencies architecture is for analysis, quantification and optimization of study plans and for monitoring student progress. The architecture establishes the specific knowledge (courses) relating them to the target competencies, establishing their implications. Incidence and relationships are expressed in qualitative values with academic credit metrics that enable measuring competencies production and the contribution of each curricular subject. Optimization enables especially the curriculum preparatory cycles. ITEMS: Teacher Productivity, Edumatics Builder, Student Auto control, Data Mining, Deductive Data Bases.

\subsection{Functional Architectures}

Specifically indicate how they can include these new technologies both for the development and construction of the MIS and its evolution in the modern corporation, combining and strategically aligning governance and productivity QUALITY towards the HE Competitiveness. These architectures help us have a $360^{\circ}$ for visualizing, diagnosing and Quantifying, as we are approaching from now to the academic superiority. They are composed by the following:

12 "Intelligent Architecture of Curricular Knowledge and Competencies for optimizing a Curriculum in Higher Education". DNDA: Book 13 - Volume 45- Item 197. (Bogotá, 2015). 


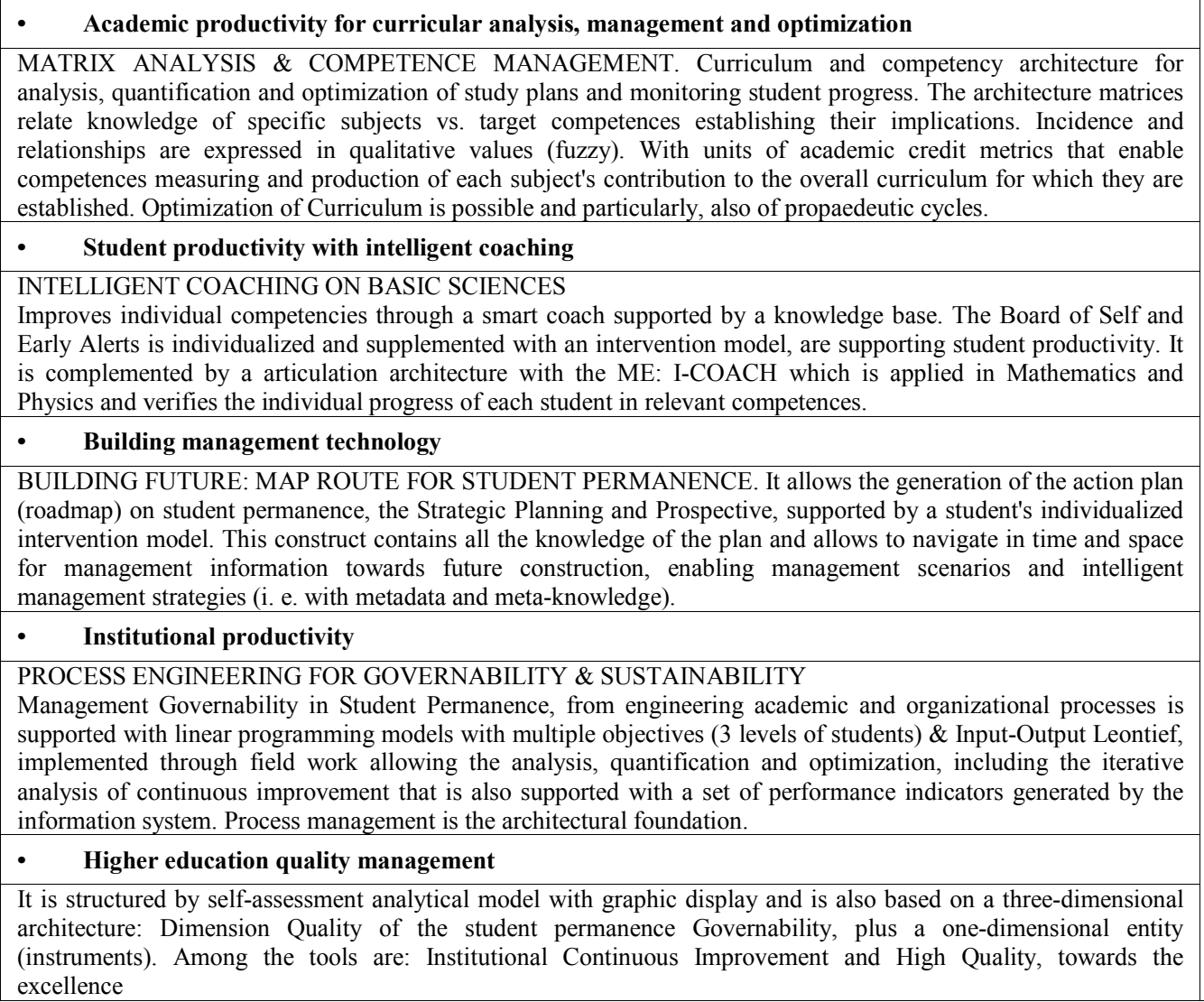

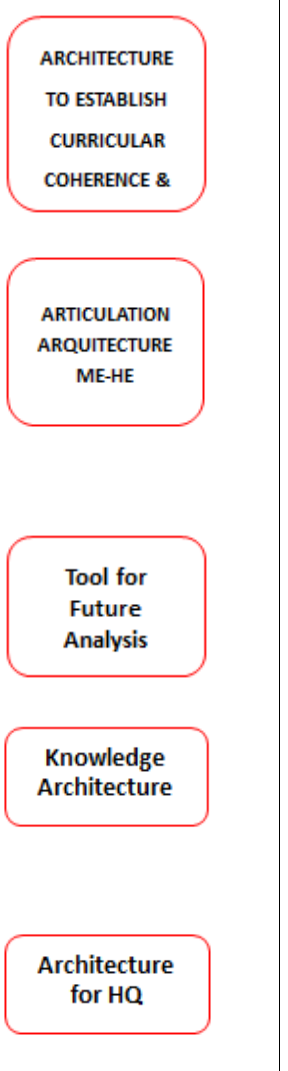

Figure 13. The 5 functional architectures for USANJOSE-ARKE.INTELL

\subsection{Student Productivity}

It's a construct based on knowledge, guided by competencies, and powered by artificial and computational intelligence $(\mathrm{ACI})$ to train engineering students in mathematics, physics and literacy. The Architecture includes: Edumatics Builder of Tests and Examinations, Student Subsystem and Administration Sub-System. Several developments have preceded these efforts.

Improving individual skills through a smart coach is supported by a knowledge base construct we called USANJOSE ICOACH-PROTY for intelligent coach in mathematics, physics and literacy ${ }^{13}$. The Self Individualized Board and Early Warnings, supplemented with an intervention model, are supporting student productivity. This is complemented by a joint architecture for ME: iCOACH applied to ICT/OLG (online government), and to verify the individual progress of each student in the relevant competences.

The Methodology aspects are mature and are worked with QTI \& IEEE International Standards. The software construct USANJOSE ADVERTOR-HE-PRODUCTIVITY, "Student Productivity Driven with Early Warning" is complementary for the architectures.

\subsection{Capabilities of Technology Management}

We present some developed tools and other complementary developments that have been implemented for several HEI in pursuing the student permanence rout map, i.e. action plan; especially complete tools for strategic planning coordinated with prospective, as well as a system for establishing curricular coherence with the competences and optimization of a study plan; these tools were built with end-user computing (Excel). [8] [21] [23] [34] [48] [50]

They allow the generation of the action plan (roadmap) for student retention by strategic planning and forecasting, supported by an individualized student intervention model. We called this construct USANJOSE-STRATEGIC -PROSPECT-PLAN, "Prospective and Strategic Planning for Student Permanence in Higher Education". 14 It contains all the knowledge of the plan and allows the user to navigate in time and space through the management information for future construction, enabling scenarios management and intelligent management of strategies (i.e. with metadata and meta-knowledge).

ITEMS: SWOT (strengths, weaknesses, opportunities, threats) Analysis, Prospective and Scenario Management; Smart Strategies, Roadmap to Permanence. 


\subsection{Corporate Productivity}

Management Governance in Student Permanence for engineering academic and organizational processes is supported by Leontief Input-Output linear programming models with multiple objectives (3 levels of students), implemented through field work allowing the analysis, quantification and optimization, including the iterative analysis of continuous improvement that is also supported with a set of indicators generated by the MIS. Process management is the architectural foundation.

ITEMS: Input-Output Matrix; Intelligent Process Methodology; Governability Model.

\subsection{Governability of Quality}

It is structured by an analytical model of self-evaluation and graphical display; it is also based on a three-dimensional architecture: Quality, Governability of student retention, and the size of entities (instruments). Among the tools are Institutional Continuous Improvement and High Quality towards Excellence. These architectures help us to have a $360^{\circ}$ to visualize, diagnose and quantify, to the extent that we are approaching now the academic superiority.

ITEMS: Quality Architecture; Self Chart Model; Continuous Improvement Model; Empowered Indicators; Academics and Management.

\section{Conclusions and the Road Ahead}

- The foregoing includes increasing large knowledge bases for verification of cultivated skills and knowledge, and batteries of intelligent questions, with protocols for designing and verification of knowledge questioning, with extensive use of international standards such as of IEEE (Software Engineering \& Higher Education Standards) and QTI (Question, \& Test Interoperability). In addition to the documentation.

- We continue to work intensively with major field testing in order to improve the pedagogical and instructional systems, and especially with the tutorial and remediation strategies aspects.

- Knowledge and Competencies Management for skills definition and their administration, and tests and examinations generation design for the individual assessments via WEB are being developed. It includes a Knowledge Base Administrator, and a statistical system is involved.

- Social Projection: A book of KEE (in Spanish) is being written with the outcomes, experiential learning, competencies and new knowledge generated by the research.

- Various papers are being submitted to several world class meetings.
- An English version of our systems USANJOSE-ARKE-INTELL is to be undertaken for abroad implementation.

\subsection{Discussion}

About our developed architectures:

- The architectural methodology illustrated us how a complex system can be composed and articulated in order to show how is the governance and relations to actors, major subsystems, and software to obtain new, important and better functionalities. This architecture conforms a big system as a whole, organized and complex.

- The architectural approach allowed us to analyze and evaluate large volume of academic and administrative information, in a well-structured way, with $360^{\circ}$ view. It also allowed us to browse the entire administrative and academic information of the University (walking-through from top down to bottom up)

- Greatly, the applied method facilitated the strategic alignment of the different units to the final strategy: the High Quality. Also it provided the synchronization of academic and administrative processes, establishing common referents to the whole community.

- The congregation of information at different levels of aggregations reduced the complexity of the analysis and design. As even it facilitated institutional improvement of plans coherently.

- The Self-Assessment itself, managed as an organizational process, facilitated with organizational metrics, the linear programming model and the Leontief input-output, extended its value for optimization purposes.

- Another important contribution is the model of SelfAssessment for HE, according to the CNA, for which we use some tools for BIG Data management and visualization, through a multivariate fuzzy matrix-dashboard with an Architectural Vision, $360^{\circ}$.

- With the self-Assessment as a process variable, i. e. it was allowed quantifying the incidence of self-Assessment in terms of quality, and academic sustainability, student desertion and many others, thanks to the knowledge architecture.

- Finally we consider that the information enterprise architecture is the Institutional memory largely expected.

\subsection{Synthesis: Outcomes of the Architecture}

As shown before, in Figure 7, we summarize the following outcomes:

- The accreditation of High quality is the verification of the completeness of the whole Institutional Quality towards the excellence: Our architectures help us 
visualize, diagnose and quantify as we are approaching to academic excellence.

- Regarding that methods of HE are changing rapidly, we are facing new challenges both at institutional and at individual levels. Due to the increase in national and international competition, institutions are struggling to offer attractive academic programs with HQ Accreditation for learners by employing modern ICT based e-learning.

- These architectures allow us to follow up the progressive enhancement in search of the academic excellence.

\subsection{Conclusions and Future Work}

Knowledge is one of the most important expressions of human intelligence, in order to:

- Confronting problems and also determining to solve them

- Addressing the complexities of human beings, society and the world

- Coping with shortages of food and resources.

- In short, knowledge appears in the Third Millennium as a cognitive tool for large applications and uses in the Knowledge Society.

- We have presented mainly a dual architecture models for handling HQ in HE: One is related to the large knowledge, data and information. The other is to verify the completeness of the requirements for accreditation purpose by National and International Agencies. Both of the mentioned are concreted in a tool.

- Perhaps the most important innovation regards the inter-industrial Leontief model by including the knowledge sector.

- Production can be quantified both for knowledge and intellectual assets, in addition to its accumulation.

- These experiences have been cataloged by the MEN as successful and allowed us the mobility of knowledge and we are implementing them in several universities in Colombia, [34].

- The Quality Architecture has been framed as a systemic one, to respond to the main problem of HE. The Accreditation process is a byproduct of this endeavor.

- We try to address the complex problem of Educational Quality, including:

- The joint HE-ME problem due to the poor preparation of young people who enter the HE in Colombia.

- The different actors in the process: teachers, students, parents, government, industry and others.

- We use complex tools, as befits the nature of the problem, such as ICT, ACI, KE, and different kinds of architectures: Data, Information, ICT and Intelligent knowledge-based Software Engineering, from many others.
- New constructs are conceptualized as Educational Intelligence as a set analogous to the BI (Business Intelligence) but with its own specific constructs.

\subsection{Future Work Purposes}

They are related to enrich intelligent architecture with Machine Learning constructs. We will improve the methodological and software experiences and developments to achieve a professional version to offer to all, local and international wide academic community. We are addressing this professional development of our tools presented above, to give them a broader social use, and to provide that they can be adapted to the specific needs of each HEI. To this end, we are seeking international resources to support our innovation and research initiatives.

Giving that the complexity of knowledge is caused by the dynamic nature of the enterprises systems of the III Millennium, and especially by how HEI in general evolves, this brings challenges to the achievement of semantic interoperability and the maintenance of managerial information \& knowledge systems. Therefore it has been required the urgent adoption of vocabularies, primarily terminologies and ontologies for $\mathrm{KE}$ and $\mathrm{KM}$ (knowledge management). It is a way for standardization of HEI knowledge representation models, as the knowledge has its ethos inside the University. We included in each Chapter, a technical glossary related to KE and $\mathrm{KM}$.

\section{Acknowledgements}

Our gratitude to U. SANJOSE's Lecturers and Officers, especially to the Cognicentre of SAN JOSÉE EIDOS International Research Team for Intelligence Developing, including Carlos F. Pareja (U. San Jose Principal), Guillermo Hoyos, Claudia Caro, Martha Rozo, Alexis Mena, Hugo Medina, Jessica Perez Gutierrez, Byron Pérez Gutiérrez, Hernán Remolina and especially to Dr. Giovanni Rozo Pardo, to all of them, our debt of thanks.

\section{REFERENCES}

[1] Aguerrondo, Inés (1996). La Escuela Como Organización Inteligente. Argentina: Troquel. ISBN 950-16-3077-3. URL Contenido y Cap. 1: https://goo.gl/6eKO2p.

[2] Aguerrondo, Inés (1996). La Escuela Transformada: Una Organización Inteligente y Una Gestión Efectiva. En La Escuela Como Organización Inteligente - Cap. 1. Argentina; Troquel. ISBN 950-16-3077-3. URL: https://goo.gl/6eKO2p.

[3] Ahmed, Mohammed; Hamdatu, Mohammed; et. al. Application of Quality Assurance \& Accreditation in the Institutes of Higher Education in the Arab World (Descriptive \& Analytical Survey) In American International Journal of Contemporary Research, Vol. 3 No. 4; April 2013, Al. College of Science \& Humanities Shaqra University - KSA. 
[4] Bahamon Lozano, José Hernando. La Gestion estratégica en el contexto de la Universidades Colombianas. Factores que inciden en su incorporación, aplicación efectiva e institucionalización. PhD Thesis, U. de Sevilla. España, Marzo de 2013.

[5] Baltodano, María Mendieta; Cobos Sanchiz, David; \& Vázquez-Cano, Esteban. (2016). La Percepción de los Docentes sobre la Funcionalidad Educo-Organizativa de las TIC en la Universidad Nacional Autónoma de Nicaragua (UNAN-Managua). En Revista Latinoamericana de Tecnología Educativa - Vol. 15 - No. 3. ISSN: 1695-288X. URL: http://relatec.unex.es/article/view/2658/1930.

[6] Bernus, P.; Nemes, L.; \& Schmidt, G. (Eds.) Handbook on Enterprise Architecture. Springer, 1 edition (November 5, 2003). (International Handbooks on Information Systems). 7ISBN-10: 3540003436. ISBN-13: 978-3540003434.

[7] Bill and Melinda Gates Foundation. (2010). Next Generation Learning: The Intelligent use of Technology to Develop Innovative Learning Models and Personalized Educational Pathways. URL:

https://docs.gatesfoundation.org/documents/nextgenlearning.p df.

[8] Bolívar, Antonio (2001). Los Centros Educativos como Organizaciones que Aprenden: Una Mirada Crítica. En Contexto Educativo, No. 18. U. Granada, España-Facultad de Ciencias de la Educación. ISSN-e 1515-7458. URL: https://goo.gl/rbakjI.

[9] Bracho, Teresa (2002). Desigualdad social y educación en México. Una perspectiva sociológica. En Educar, No. 29. Pp. 31-54. Centro de Investigación y Docencia Económicas (CIDE). México. ISSN 0211-819X. URL: https://goo.gl/zV1sNA.

[10] Callaghan, Victor (Essex U.); Zheng, Ping; \&WU, Hsuan-Yi. (2012). Guanajuato (México). An Entrepreneurship Model for Future Intelligent Educational Environments. In Future Intelligent Educational Environments. URL:

https://goo.gl/OgZaeF.

[11] Cano García, Elena (2008). La Evaluación por Competencias en la Educación Superior. En Profesorado. Revista de Curriculum y Formación del Profesorado - vol. 12 - no. 3. U. de Barcelona. - Grupo de Investigación FORCE (Formación Centrada en la escuela). ISSN: 1138-414X, 1989-639X. URI: http://hdl.handle.net/10481/15189.

[12] Chatti, M. A.; Dyckhoff A. L.; Schroeder, U; \& Thüs, H. (2012). A Reference Model for Learning Analytics. In International Journal of Technology Enhanced Learning Special Issue on State of the Art in TEL. (Vol. 4 - issue 5/6). Pp. 318-331. Aachen University. DOI: https://doi.org/10.1504/IJTEL.2012.051815. URL: https://goo.gl/zQlWyf.

[13] Consejo Nacional de Acreditación, CNA. (Enero de 2013). Lineamientos para la acreditación de programas de pregrado. Obtenido de CNA.gov.co: http://www.cna.gov.co/

[14] Dongming Xu Huaiqing Wang Kaile Su (2002). Intelligent student profiling with fuzzy models. In Proceedings of the 35th Annual Hawaii International Conference on System Sciences. Pp: 8. IEEE Computer Society. ISBN 0-7695-1435-9. DOI https://doi.org/10.1109/HICSS.2002.994005.

[15] Ezechil, Liliana (2013). New Perspectives on Evaluation and
Certifying the Competences of Higher Education Graduates. Ezechil, Liliana (2013). University of Pitesti, Faculty of Educational Sciences, (Romania). "5th International Conference EDU-WORLD 2012 - Education Facing Contemporary World Issues". In: Procedia - social and Behavioral Sciences - Vol. 76 - No. 15. Pp. 7-12. DOI: http://dx.doi.org/10.1016/j.sbspro.2013.04.064. URL; https://goo.gl/08AqLU.

[16] FESSANJOSE is part of Internationalization Accompaniment Project awarded by the Ministry of National Education supported by the YALE UNIVERSITY and KENTUCKY STATE UNIVERSITY.

[17] FESSANJOSE under the "National Agreement to Reduce Student Attrition in Higher Education", which was signed on November 22, 2010, executed the 755 Agreement with the MEN which aimed at strengthening policies, strategies and actions of the anti-dropout program that promotes our institution in favor of the desertion of young people enrolled and in accordance with the social project that promotes access to Higher Education. (Spanish).

[18] Gabureanu, Simona; \& Istrate, Olimpius (2013). The Effects of using Intelligent Tutoring Systems for Language Learning Findings of a Research Evaluation Report. En: Procedia social and Behavioral Sciences - Vol. 76 - No. 15. Pp. 351-5. U. Politehnica of Bucharest, U. of Bucharest, (Romania). " 5 th International Conference EDU-WORLD 2012 - Education Facing Contemporary World Issues". DOI: http://dx.doi.org/10.1016/j.sbspro.2013.04.126. URL: https://goo.gl/bqns3o.

[19] García Areito, L; Ruiz Corbella, M.; \& García Blanco, M. (2009). Claves para la Educación: Actores, Agentes y Escenarios en la Sociedad Actual. Madrid: Narcea/UNED. SBN 9788427716247. 340 p.

[20] Ginés Mora, José. La Necesidad del Cambio Educativo para la Sociedad del Conocimiento. En Revista Iberoamericana de Educación, mayo-agosto de 2004, No. 35, pp. 13-37. Madrid, OEI. ISBN: 1022-6508-X, 1681-5653. URL: http://www.redalyc.org/pdf/800/80003503.pdf.

[21] Kurshan, Barbara (2016). The Future of Artificial Intelligence in Education. Forbes Education. URL, Feb, 12/17 https://goo.gl/xVbtvl.

[22] Luckin, Rose; Holmes, Wayne; Griffiths, Mark; \& Forcier, Laurie B. (2016). Intelligence Unleashed: An argument for AI in Education. London: Pearson. URL: https://goo.gl/GTVO9K.

[23] Magalhães, T; Portela, F; \& Santos, M. F. (2014). Multi-Model and Pervasive Intelligent Decision Support System for University Application. In ICERI2014 Proceedings. Pp. 5035-5041. University of Minho (Portugal). "7th International Conference of Education, Research and Innovation". ISBN: 978-84-617-2484-0. ISSN: 2340-1095. URL: https://library.iated.org/view/MAGALHAES2014MUL.

[24] María José Lemaitre et al (Eds.). Aseguramiento de la calidad en Iberoamérica. In Educación Superior en Iberoamérica Informe 2012. Santiago, Chile: Universia/CINDA, 2012. ISBN 978956 7106-60-8.

[25] MEN Convocation 2013: NATIONAL AGREEMENT TO REDUCE STUDENT DROP OUT. Projects directed to transfer strategies that promote the permanence and graduation in higher education. (Spanish) 
[26] Ministerio de Educación Nacional. Portafolio de Modelos Educativos. Colombia Aprende - Portafolio de Modelos Educativos Flexibles, https://goo.gl/xJnU5B. URL: https://goo.gl/9e6aRG.

[27] Mora Cortes, Andres. La Psudorevolución Educativa, Desigualdades, Capitalismo y Control en la Educación Superior en Colombia. Ed. Universidad Javeriana, 2016. Colección Ciencia Política.

[28] Morin, Edgar. Seven Complex Lessons in Education for the Future. Paris: UNESCO, 2002. ISBN-13: 978-9231037788, ISBN-10: 9231037781. URL

http://www.unesco.org/education/tlsf/mods/theme_a/img/03_ sevenlessons.pdf.

[29] Murueta, Marco Eduardo (2017). Nuevos Modelos Educativos. In II Congreso Internacional de Transformación Educativa Alternativas para Nuevas Prácticas Educativas, No. 8. México: Amapsi. ISBN: 978-607-7506-21-8. URL: https://goo.gl/pB1Eb6.

[30] Nicolescu, Bogdan N.; \& Petrescu, Tudor C. (2013). Dynamical Systems Theory - A Powerful Tool in the Educational Sciences. In Procedia - social and Behavioral Sciences - Vol. 76 - No. 15. Pp. 581-7. University of Pitesti (Romania). "5th International Conference EDU-WORLD 2012 - Education Facing Contemporary World Issues". DOI: http://dx.doi.org/10.1016/j.sbspro.2013.04.168. URL: https://goo.gl/61JndV.

[31] OECD, IBRD \& THE WORLD BANK. Tertiary Education in Colombia; Reviews of National Policies for Education: Tertiary Education in Colombia - OECD Publishing, 2012. DOI: $10.1787 / 9789264180697-$ en.

[32] Peelo, Moira T.; Wareham, Terry (Eds.). (2002). Failing Students in Higher Education. Society for Research into Higher Education. ISBN-13: 978-0335208265. ISBN-10: 0335208266 .

[33] Peña, Clara Inés; Marzo, José L.; De la Rosa, Josep Luis; \& Fabregar, Ramón. (2002). Un sistema de Tutoría Inteligente Adaptativo Considerando Estilos de Aprendizaje.. U. Industrial de Santander (Colombia) / U. de Girona (España). En: UIS Ingenierías, Revista de la Facultad de Ingenierías Físico Mecánicas, Vol. 1. No. 2. ISSN 2145-8456. URL: https://goo.gl/2t3h9j.

[34] Pérez Ferra, Miguel (2000). La Escuela como Organización que Aprende: Una Tensión entre Cultura Escolar y las Creencias Profesionales de los Profesores. En Enseñanza, 17-18, pp. 201-216. U. de Jaén. ISSN 0212-5374. URL: http://e-spacio.uned.es/fez/eserv/bibliuned:20494/escuela_org anizacion.pdf.

[35] Pérez Gama A. et al. Education Software Architecture: Facing Student Desertion in Colombia Higher Education with an Intelligent Knowledge Based Coaching System. Bogotá Colombia: IEEE ANDESCON, 2010. ISBN 978-1-4244-7172-0.

[36] Pérez Gama, A. et al. Knowledge for the Society: Social Inclusion to the Superior Education High Competitiveness: A Knowledge-Based Governability Model for the Higher Education in Colombia by Propaedeutic Cycles. In IEEE EDUCON 2011 Annual AMMAN JORDAN. ISBN: 978-1-61284-641-5

[37] Pérez Gama, A. et al. Modelo Analítico-Inteligente de los
Ciclos Propedéuticos. Incluido en BANCO DE EXPERIENCIAS SIGNIFICATIVAS EN EDUCACION SUPERIOR. Bgotá: Ministerio de Educación Nacional, 2010. http://www.colombiaaprende.edu.co/

[38] Pérez Gama, A. et al. Prevention and Remediation of Desertion System towards the Academic Improvement: An Approach Bio-Psycho-Socio-Techno-Scientific to address Desertion and Permanence in Higher Education. (Spanish). In National Meeting of Success Cases on Desertion for Higher Education. Bogotá: FODESEP, Ministry of National Education, September 2013.

[39] Pérez Gama, A., et.al. Compendium of Quality and Government, Student Desertion and Permanence (Spanish). Bogotá: Fundación de Educación Superior San José: Febrero de 2013. ISBN: 978-958-46-1442-1.

[40] Pérez Gama, Alfonso. Analytical Models for Tertiary Education by Propaedeutic Cycles Applying Knowledge Engineering and Knowledge Management. In Huei-Tse (Ed.), New Research on Knowledge Management Models and Methods (Ch. 2, pp. 23-64). INTECH: 2012. ISBN 979-953-307-226-4.

[41] Pérez Gama, Alfonso; Andrey Ali Alvarez Gaitán, Intellectual Assets and Knowledge Method: A Contribution. In Eds Lorna UDEN et al., Advances in Intelligent Systems. London: Springer Heidelberg. 172 ISSN 2194-5357.

[42] Ricaurte, Paola (2016). Pedagogies for the open knowledge society. Humanities and Social Sciences, Tecnologico de Monterrey, Mexico. In International Journal of Educational Technology in Higher Education, Vol 13, No. 1. Pp: 13-32. ISSN 2365-9440. DOI: 10.1186/s41239-016-0033-y. URL: https://goo.gl/DnlZ3y.

[43] Rickinson, Barbara; \& Rutherford, Desmond. (1996, 2007). Systematic Monitoring of the Adjustment to University of Undergraduates: A Strategy for Reducing Withdrawal Rates. In: British Journal of Guidance \& Counselling, Vol. 24, - Issue 2. Pp. 213-225. U. of Birmingham. DOI: http://dx.doi.org/10.1080/03069889608260410.

[44] Rigo, Daiana Yamila; \& Donolo, Danilo. (2014). Contextos Educativos Inteligentes. En RIDE, Revista Iberoamericana para la Investigación y el Desarrollo Educativo - Vol. 4, No. 8. U. Nacional de Río Cuarto (Argentina). ISSN 2007-7467. URL: https://goo.gl/jpq2u8.

[45] Salazar, María Angélica (2006). El Liderazgo Transformacional ¿Modelo para Organizaciones Educativas que Aprenden? En UNIRevista - Vol. 1 - No. 3. U. de Viña del Mar (Chile). ISSN 1809-4651. URL: https://goo.gl/aeDkuJ.

[46] Serban, Andreea M.; \& Luan, Jing (Eds). (2002). Knowledge Management: Building a Competitive Advantage in Higher Education. Institutional Research No. 113, Special Issue. ISBN: 978-0-7879-6291-3. $125 \mathrm{p}$.

[47] Soare, Emanuel (2013). A Pedagogical Model for Evaluation of Students' Competences. In Procedia - social and Behavioral Sciences - Vol. 76 - No. 15. Pp. 1-6. University of Pitesti, Faculty of Educational Sciences (Romania). "5th International Conference EDU-WORLD 2012 - Education Facing Contemporary World Issues". DOI http://dx.doi.org/10.1016/j.sbspro.2013.04.063. URL https://goo.gl/QWUgWT. 
[48] Spady, William (1971). Dropouts from higher education: Toward an empirical model. In Interchange, Vol 2, No. 3. Pp: 38-62. ISSN 0826-4805. DOI: http://link.springer.com/10.1007/BF02282469.

[49] Staskeviciute, Inga; Neverauskas, Bronius (2008). The Intelligent University's Conceptual Model. En: Engineering Economics, NO 4 (59). ISSN 1392-2785. URL: http://www.kalbos.ktu.lt/index.php/EE/article/viewFile/11582 $/ 6266$.

[50] Surugiu, Mina S; Surugiu, F. I.; \& Georgiana Cristea, V. (2014). Generating Competitive Intelligence within Higher Education Institutions. Case Study in Constanta Maritime University. In Review of Applied Socio-Economic Research, Vol. 7, No. 1. ISSN: 2247-6172; ISSN-L: 2247-6172. URL: https://goo.gl/DRihoU.

[51] Susnea, Elena (2013). Improving Decision Making Process in Universities: A Conceptual Model of Intelligent Decision Support System". In Procedia - social and Behavioral Sciences - Vol. 76 - No. 15. Pp. 795-800. National Defence U. (Romania). "5th International Conference EDU-WORLD 2012 - Education Facing Contemporary World Issues”. DOI http://dx.doi.org/10.1016/j.sbspro.2013.04.208. URL https://goo.gl/tp7TNr.

[52] The Economist - Intellligence Unit (2015). Connecting Universities: Future Models of Higher Education Analyzing Innovative Models for Afghanistan, Bangladesh, India, Nepal, Pakistan and Sri Lanka. The British Council. URL: https://goo.gl/Ua5JPn.
[53] Tinto, Vincent (1975). Dropouts from higher education: A Theoretical Synthesis of Recent Research. In Review of Educational Research, Vol. 45, No. 1. Pp. 89-125 URL (1973): http://files.eric.ed.gov/fulltext/ED078802.pdf.

[54] Urretavizcaya Loinaz, Maite (2001). Sistemas Inteligentes en el Ámbito de la Educación. En: Revista Iberoamericana de Inteligencia Artificial - No. 12. Pp. 5-12. Dep. Lenguajes y Sistemas Informáticos, Fac. Informática. ISSN 1137-3601. URL: https://goo.gl/qKJGTz.

[55] Vásquez Córdova, Alejandro (2010). Competencias Cognitivas en Educación Superior. En Revista Electrónica de Desarrollo de Competencias, No. 6, Vol, 2. U. de Talca Instituto de Investigación y Desarrollo Educacional, Chile. URL:

http://redec.utalca.cl/index.php/redec/article/view/50/53.

[56] Villanueva Ernesto Fernando. Alcances y Perspectivas de los Sistemas de Aseguramiento de la Calidad Educativa En América Latina. En La Educación -Revista Digital, n. 142. OEA: Enero 2016.

[57] Weinberg, Gregorio (1984). Modelos Educativos en la Historia de América Latina. Buenos Aires: UNESCO, CEPAL, PNUD. 1ra. Ed. ISBN 95-0-136117-9. URL $1 \mathrm{https} / / /$ goo.gl/hXv69c, $1.2 \mathrm{https}: / /$ goo.gl/6kWK3v, $1.3 \mathrm{https} / /$ goo.gl/oli6Uo, 1.5 https://goo.gl/L2IqVs, 2.2 https://goo.gl/ABdOKf.

[58] Wimshurst, Kerry; \& Wortley, Richard. (2004). Academic Success and Failure: Student Characteristics and Broader Implications for Research in Higher Education. In ETL Conference. Griffith University. URL: https://goo.gl/BjwuiP. 